\title{
Colombia's experience \\ with reserve requirements on capital inflows
}

\section{José Antonio Ocampo \\ United Nations Under- \\ Secretary-General for \\ Economic and Social \\ Affairs and former \\ Executive Secretary of ECLAC \\ jaocampo@un.org \\ Camilo E. Tovar \\ Department of Economics, \\ University of Wisconsin-Madison \\ cetovar@wisc.edu}

Smoothing out capital-account cycles and reducing their vulnerability are desirable policy objectives in developing countries. This paper evaluates the advantages of a simple, non-discretionary, preventive (prudential) price-based incentive that severely penalizes short-term foreign currency liabilities. In particular, it examines the effectiveness of controls on capital inflows in Colombia during the 1990s. The analysis finds evidence supporting the conclusion that these controls were effective in reducing the overall volume of net capital inflows and that they helped to improve the term structure of foreign borrowing. An econometric analysis suggests that capital flows were directly related to interest rate differentials, controlling for the additional cost imposed by unremunerated reserve requirements on foreign borrowing. Hence, the Colombian system of controls on foreign borrowing was both an effective macroeconomic policy that allowed the country to gain a degree of monetary and exchange-rate control and a useful "liability policy" that helped improve the term structure of its foreign debt. 


\section{I}

\section{Introduction}

It is now widely recognized that developing countries - and particularly emerging economies - are extremely vulnerable to fluctuations in international capital flows. The high economic and social costs entailed in sudden reversals of these flows, especially when they lead to financial crises, may easily outweigh the potential gains offered by increased capital mobility. As a result, an essential objective of macroeconomic policy is to reduce the intensity of capital-account cycles with a view to realizing the benefits of international financial integration while reducing the macroeconomic instability and financial vulnerability associated with these cycles. ${ }^{1}$

In the 1990s, most emerging economies had to deal with large capital inflows. ${ }^{2}$ Policy responses to them, although diverse, ${ }^{3}$ reflected the common aim of mitigating their effects in terms of both appreciation pressures and excessive reliance on short-term capital inflows. ${ }^{4}$ To avoid financial crises in the future, it will be critical to determine which of the policies applied during this period proved effective in managing such capital surges and, in particular, in preventing the excessive accumulation of risk that in some cases led to financial crises or outright meltdowns when there was a sudden interruption of external financing.

The recent literature has emphasized that crisis prevention strategies should involve the adoption of countercyclical (i.e., in that phase of the cycle,

$\square$ We appreciate the helpful comments and suggestions made on a previous version of this paper by Sylvia Díaz, Charles Engel, Yuichi Kitamura, Jorge Tovar and Kenneth West.

${ }^{1}$ Gourinchas, Valdés and Landerretche (2001) provide a detailed account of the different sources of such vulnerability.

${ }^{2}$ For a review of the factors driving these surges in capital flows to developing countries, see Calvo, Leiderman and Reinhart (1996).

${ }^{3}$ Fiscal austerity measures, accelerated trade liberalization, increased exchange rate flexibility, sterilized intervention, liberalization of capital outflows and controls on capital inflows were the main policies used to deal with surges in capital inflows. A good review of them can be found in Reinhart and Dunaway (1996).

${ }^{4}$ Indeed, cumulative exchange rate appreciation and, especially, excessive reliance on short-term foreign liabilities appear to be key determinants of recent financial crises. See Furman and Stiglitz (1998) and Rodrik and Velasco (2000). contractionary) macroeconomic policies during periods of capital-account surges and the development of strong prudential regulations and supervision frameworks for domestic financial systems. It is also recognized, however, that while these approaches are both necessary and desirable, countercyclical macroeconomic policies may be compromised during boom periods by the additional capital inflows they induce (e.g., the larger flows generated by sterilized monetary intervention via its impact on interest rates). Moreover, it is recognized that the effects of prudential regulation can be circumvented through direct borrowing abroad. This implies that it may be useful to complement such preventive policies with policy instruments aimed directly at the source of the macroeconomic and financial pressures faced by developing countries during boom periods - i.e., excessive capital inflows. ${ }^{5}$

In this regard, a policy that has been considered to be potentially effective involves the application of pricebased controls on capital inflows - i.e., an unremunerated deposit or reserve requirement on foreign borrowing. ${ }^{6}$ In particular, it has been argued that this type of capital-account regulation could be useful both as a macroeconomic policy tool and as a "liability policy" for improving the debt profile of developing countries.

Viewed as a macroeconomic policy tool, such regulations aim directly at the source of boom-bust cycles: unstable capital flows. If they succeed in reducing total capital inflows, they will provide some room to "lean against the wind" during periods of financial euphoria through the adoption of a contractionary monetary policy and/or reduced exchange-rate appreciation pressures. If effective, they will also reduce or eliminate the quasi-fiscal costs associated with sterilized foreign-exchange accumulation.

\footnotetext{
5 See Furman and Stiglitz (1998), Williamson and Mahar (1998), Eichengreen (1999) and Ocampo (2003a and 2003b).

${ }^{6}$ Although "reserve requirement" will be used most of the time, the term "deposit" (at the central bank) will also be used in this paper as a synonym.
} 
Viewed as a liability policy, such regulations recognize the fact that the market rewards sound external debt profiles (Rodrik and Velasco, 2000). This reflects the fact that, during times of uncertainty, the market responds to gross (rather than merely net) financing requirements, which means that the rollover of shortterm liabilities is not financially neutral. Under these circumstances, a maturity profile that leans towards longer-term obligations will reduce illiquidity risks. This indicates that measures to improve the maturity structures of both the private and public sectors' external and domestic liabilities should be an essential component of economic policy management during booms.

Broadly speaking, the existing empirical literature supports the "liability policy" effects of price-based controls - i.e., the fact that they discourage short-term capital inflows and thus improve the maturity profile of external liabilities. However, the question of whether these controls reduce net capital inflows and ease pressures on the exchange rate is still a matter of controversy. In fact, few empirical studies have analysed these issues, and the evidence relies mostly on the Chilean experience. ${ }^{7}$

This paper will address the issue of the effectiveness of price-based controls on capital inflows based on Colombia's experience in the 1990s. In particular, it examines whether these controls influenced the level and composition of financial inflows. Following this introduction, the rest of the paper is organized as follows. Section II presents an overview of the Colombian regulatory framework for foreignexchange transactions in the 1990s. Section III discusses the conceptual framework of the analysis. Section IV presents econometric evidence of the impact of capital controls on the level and term structure of net private cash capital flows. This is complemented with an analysis of the sensitivity of capital flows to interest rate differentials before and after the capital account was liberalized in Colombia. A number of complementary econometric exercises are employed for this purpose. Finally, some concluding remarks are presented in section V.

\section{II}

\section{Colombian capital-account}

\section{regulation}

Colombia liberalized foreign-exchange transactions in the early 1990s as part of a broader programme of structural reforms. The initial stage of this process took place in 1991, when the foreign-exchange control system that had prevailed for a quarter of a century was modified in order to allow financial intermediaries to manage foreign transactions without being subject to prior controls by the central bank (Banco de la República) and to allow firms to use their bank accounts to manage foreign-exchange revenues and expenditures. Despite this liberalization, transactions continued to be highly regulated and, in particular, remained subject to

\footnotetext{
${ }^{7}$ Studies on the effects of reserve requirements in Chile include De Gregorio, Edwards and Valdés (2000), Edwards (1999 and 1998), Agosin and Ffrench-Davis (1999 and 1996), Budnevich and Le Fort (1997) and Valdés and Soto (1998). For a general overview, see Montiel and Reinhart (1999).
}

the requirement that they should be channelled through financial intermediaries that were legally authorized to operate in the market. Additionally, the 1991 reform established a minimum maturity of one year for foreign loans ${ }^{8}$ and maintained strict regulations on the final use of funds from such loans, which had to be used for trade or investment financing. In February 1992, for the first time, firms were allowed to contract short-term credits for use as working capital.

It was not until September 1993 that more sweeping changes were introduced. During this second stage of reforms, the system of regulating capital flows based on their final use was replaced by a system based on the maturities of foreign-currency obligations. Additionally, domestic financial intermediaries were

\footnotetext{
${ }^{8}$ Some exceptions were granted for specific commercial credits.
} 


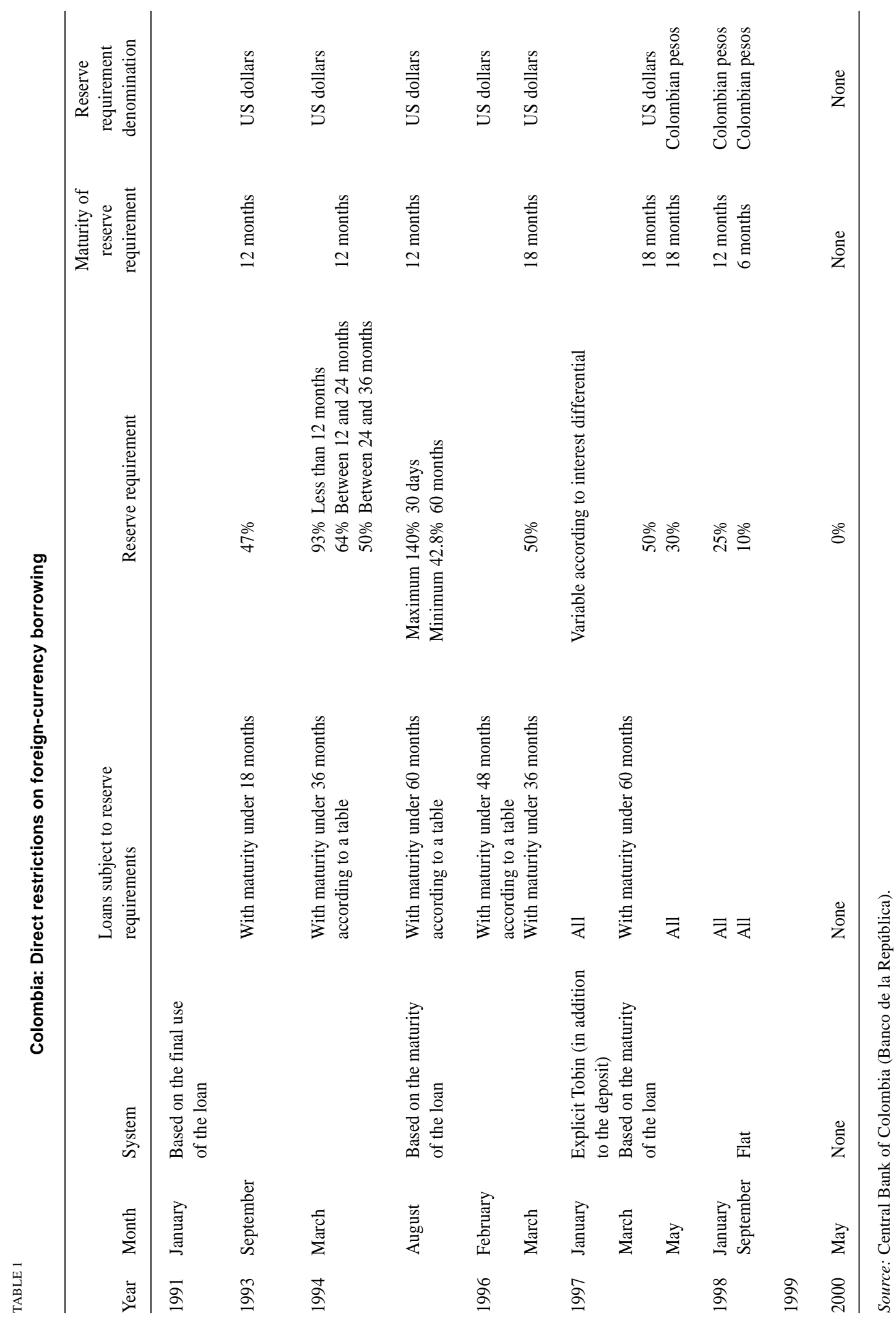


authorized to lend in foreign currency to domestic firms and residents regardless of the final use of the credit, to lend to foreigners in international currencies and to invest liquid assets abroad. However, all debts denominated in foreign currency had to be registered with the central bank, including short-term commercial credits (which previously had not been subject to this requirement).

More specifically, the new system required a dollardenominated reserve to be deposited in the central bank for all loans of less than a certain maturity (referred to here as the minimum maturity), at a pre-specified rate and for a predetermined holding period. In fact, the reserve requirement was akin to a tax, as it could be immediately redeemed at pre-established discount rates. ${ }^{9}$ The system underwent major changes in subsequent years, however, as summarized in table 1 . In September 1993, a dollar denominated one-year reserve requirement of $47 \%$ was established for all loans with terms below a minimum of 18 months. ${ }^{10}$ In March 1994, the minimum maturity was set at three years and three types of dollar reserve requirements were established $93 \%$ for loans with maturities up to one year, $64 \%$ for those with maturities up to two years, and $50 \%$ for those with maturities up to three years. In August 1994, the minimum maturity was increased to five years and the maturity of the deposit was matched with that of the loan. The reserve requirement corresponded to a complex table, with a ceiling of $140 \%$ for loans maturing in less than 30 days and a floor of $42 \%$ for loans maturing in five years. In February 1996, the minimum maturity was shortened to four years and a new reserve requirement table was established. In March of that year, the minimum maturity was shortened again, to three years, and a flat deposit rate was established, equivalent to $50 \%$ of the loan, with an 18-month maturity.

In January 1997, the government imposed an explicit (Tobin) tax on all capital flows, in addition to the reserve requirement. This tax was short-lived, however, since it was decreed unconstitutional in March. In response to the Constitutional Court's ruling, the economic authorities immediately imposed stricter reserve requirements on foreign borrowing. The minimum maturity was raised to five years and the deposit table was maintained. In May 1997, a simpler system, similar to the one used in Chile, was introduced. The new system established a flat reserve requirement in local currency with an 18-month maturity for all loans. The principle of minimum maturity was therefore abandoned and peso-denominated reserve requirements replaced the dollar-denominated ones. In January and September 1998, the reserve requirement rate and holding periods were reduced in response to the pressures created by the international financial crisis. The reserve requirement was finally eliminated in May 2000 , though the authorities retained the option of reestablishing it.

\section{III}

\section{Conceptual framework}

A simple portfolio framework based on the interest parity condition will be used to analyse the effects of regulation of private capital flows. ${ }^{11-12}$ Accordingly, under perfect substitutability of domestic and foreign assets, a risk-neutral investor will choose to hold foreign

\footnotetext{
${ }^{9}$ Although this was a non-remunerated reserve requirement, this did not mean that it could not have positive or negative returns. In fact, such returns could arise owing to changes in the relative value of the currency in which the deposit was made.

${ }^{10}$ This means that a one-year reserve requirement of US $\$ 47$ had to be held at the central bank (Banco de la República) for every US\$ 100 borrowed abroad.
}

or domestic assets based on the uncovered interest rate differential or arbitrage factor; i.e., the difference between domestic interest rates and foreign interest

\footnotetext{
${ }^{11}$ See Frankel (1992) and Schulze (2000) for a discussion of how to measure capital mobility.

${ }^{12}$ An alternative would be to use an asset-pricing model framework. However, the problem with using these models to test for the existence of barriers to international investment is that such tests typically lack explanatory power. Tests that use market integration as the null hypothesis cannot econometrically reject the existence of significant barriers because the estimates are too imprecise. See Schulze (2000), p. 162.
} 
rates plus expected devaluation. Formally, this may be expressed as:

$$
\mathrm{A}=\frac{1+i}{\left(1+i^{*}\right)\left(1+d^{e}\right)}-1
$$

where $i$ is the domestic interest (deposit) rate, $i^{*}$ is the equivalent foreign interest rate and $d^{e}$ is the expected devaluation. If $A>0$, investors will prefer domestic assets and, consequently, the country will experience capital inflows. On the other hand, if $A<0$, investors will prefer foreign assets, and the country will experience capital outflows. Lastly, investors will display no preference for either domestic or foreign assets if $A=0$, in which case their portfolio will be in equilibrium and there will be no capital flows associated with arbitrage factors.

In the presence of the reserve requirement on capital inflows, however, the arbitrage factor needs to be adjusted to take into account the opportunity cost of such requirements. ${ }^{13}$ As a result, the interest differential may be calculated as:

$$
\mathrm{A}=\frac{1+i}{1+\phi}-1
$$

where $\phi$ is the (discounted) total annual cost of the foreign loan. The precise expression for cost $\phi$ can be derived from the fact that the present value of reserve requirements per dollar borrowed, $C$, is:

$$
\mathrm{C}=\mathrm{r}\left(1-\frac{1+d^{e} \theta}{1+i}\right)^{t d}
$$

where $r$ is the reserve requirement rate per dollar borrowed abroad and $t d$ is the maturity of the deposit. In adition, for the period when reserve requirements were dollar-denominated (September-May 1997),

\footnotetext{
${ }^{13}$ The framework used in this paper assumes imperfect substitution of domestic and foreign assets. Theoretically, a country-risk premium should be included in the analysis. However, there is no consistent measure of Colombia's country-risk premiums during the period of analysis. An implicit assumption is thus that risk premiums are dependent on the factors that are included in the analysis - i.e., capital regulations and the dummies that capture the external financial environment.
}

$\theta$ equals 1 , whereas for the period when they were pesodenominated (May 1997-May 2000), $\theta$ equals 0.

Given equation 3 , the future value of reserve requirements may be calculated as follows: ${ }^{14}$

$$
L f=\left[\left(1+i^{*}\right)\left(1+d^{e} \theta\right)\right]^{t c}+C(1+\mathrm{i})^{t c}
$$

where $t c$ is the maturity of the loan. Therefore, using equation 4 , it is possible to calculate the total annual cost of the loan, $\phi$ :

$$
\phi=L f^{(1 / \mathrm{tc})}-1
$$

which is used in equation 2 to calculate the arbitrage factor. Finally, the tax equivalent of reserve requirements on foreign borrowing can be calculated using the following expression:

$$
\tau=\frac{1+\phi}{\left(1+i^{*}\right)\left(1+d^{e}\right)}-1
$$

The tax equivalent of reserve requirements is a function of three main variables: (i) the deposit rate (r); (ii) the ratio of the maturity of the loan to the maturity of the reserve requirement; and (iii) the fact that, when the reserve requirements were dollardenominated (between September 1993 and May 1997), their opportunity cost was positively related to interest rates and inversely related to the devaluation rate. This last effect was exactly opposite to the direct effect of the devaluation rate on the cost of foreign borrowing, which allowed the reserve requirement to act as a (partial) stabilizer on the cost of foreign borrowing. Indeed, lower borrowing costs due to a slow rate of devaluation or appreciation of the exchange rate increased the tax equivalent of the reserve requirement, while the opposite occurred if borrowing costs increased because of a faster devaluation rate. This stabilizing effect was lost after May 1997, however, when the dollar reserve requirement was replaced with the pesodenominated scheme.

\footnotetext{
${ }^{14}$ Since the maturities of the reserve requirement and the loan may differ, it is easier to calculate the future value of the reserve requirement.
} 
FIGURE 1

\section{Colombia: Total cost of foreign borrowing}

A. Effects of reserve requirements on the relative cost of foreign borrowing

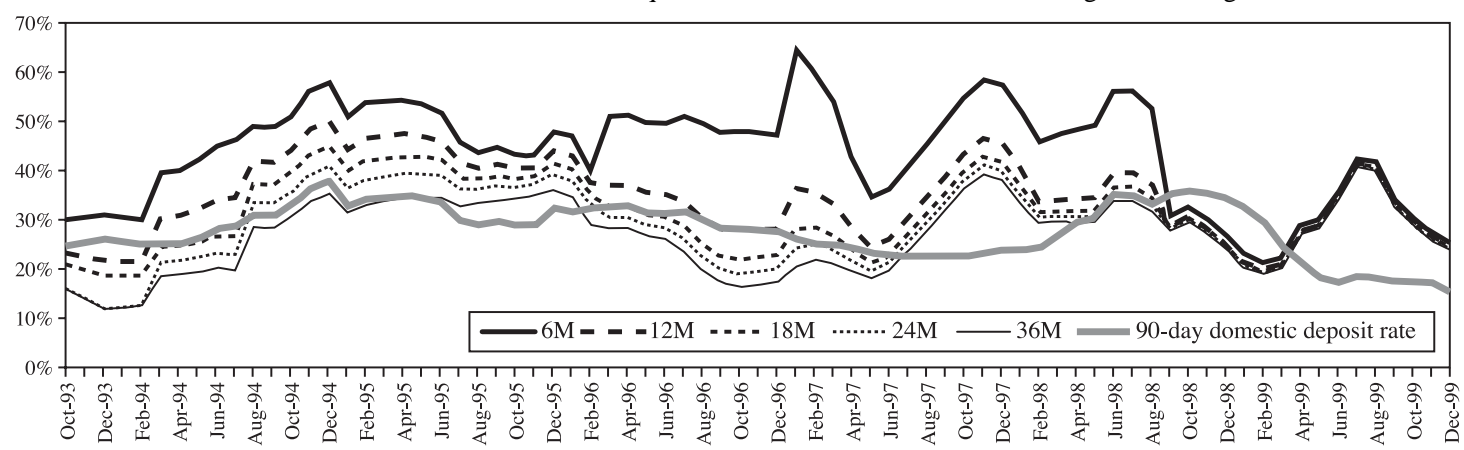

B. Tax equivalent of reserve requirements

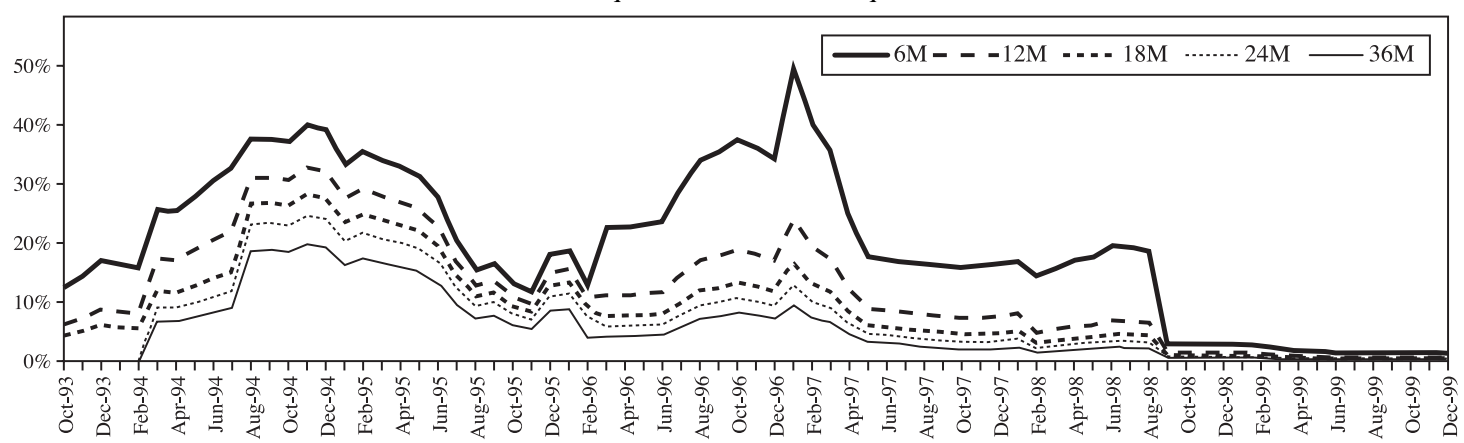

C. Annual devaluation

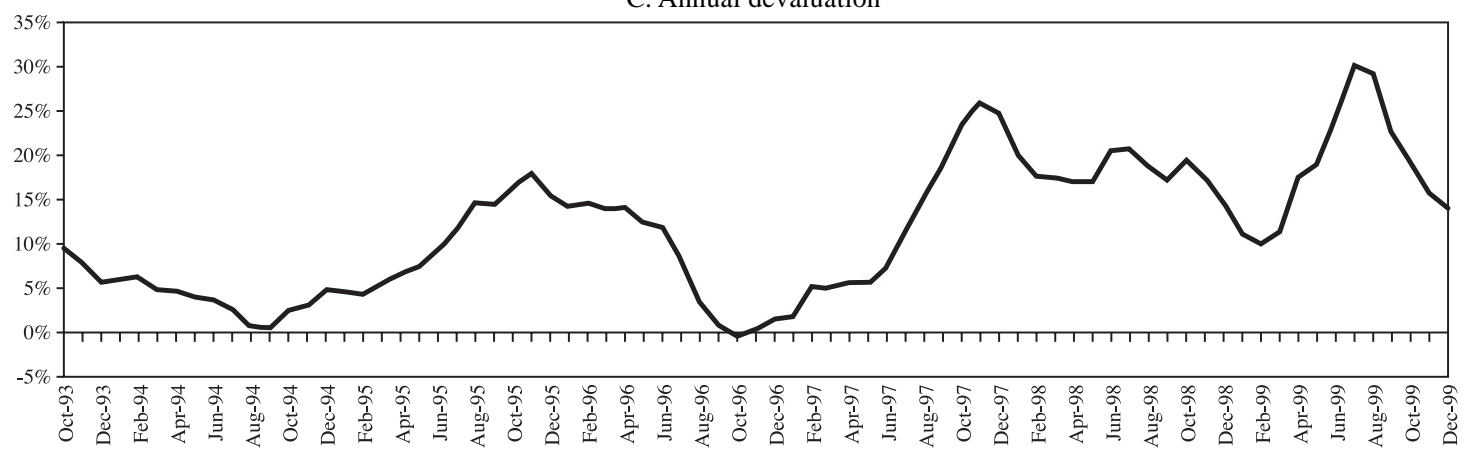

Source: Calculations based on data from the Central Bank of Colombia (Banco de la República).

Figure 1 shows the calculation of the total cost of foreign borrowing and the tax equivalent of the reserve requirement for loans of $6,12,18,24$ and 36 months, ${ }^{15}$

${ }^{15}$ For the purposes of the calculation, $i$ is the 90-day domestic (passive or deposit) interest rate, $i *$ is the equivalent United States interest rate and $d^{e}$ was calculated using a linear combination of annualized nominal devaluation in the 12 preceding and 12 following months, giving equal weights to each observation. and the annual nominal devaluation rate. These figures show that regulations made short-term foreign borrowing very expensive for most of the decade, especially in the case of 6-month loans. It should be noted, however, that until early 1997 the high cost of foreign borrowing was associated with trends in the tax equivalent of reserve requirements. However, after the May 1997 regulatory change, the high cost of foreign borrowing basically reflected strong devaluation 
FIGURE 2

\section{Colombia: Interest rate differentials and private cash capital flows}

A. Interest rate differentials

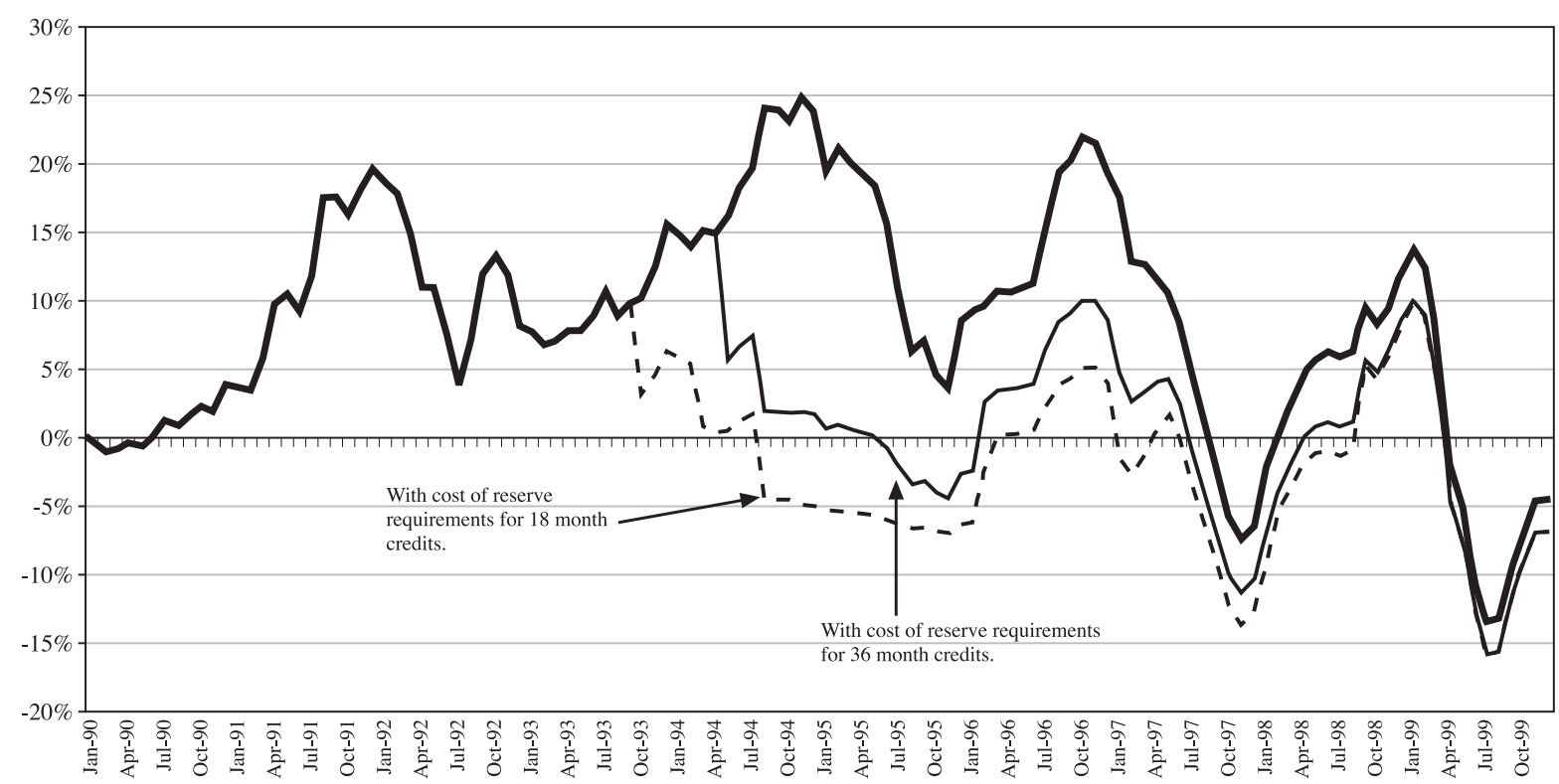

B. Private cash capital flows

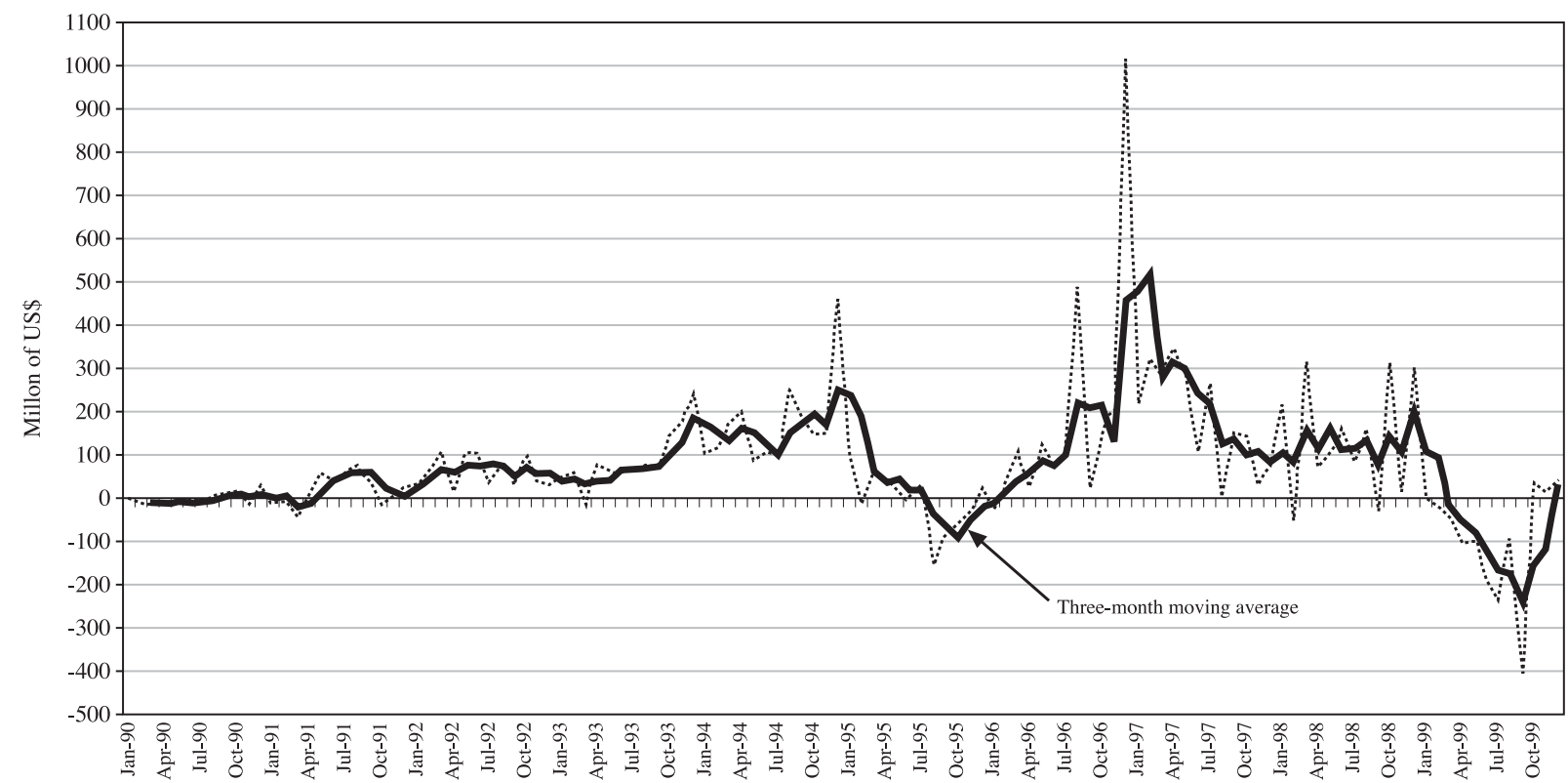

Source: Calculations based on data from the Central Bank of Colombia (Banco de la República). 
pressures on the nominal exchange rate associated with the international financial crises prevailing at the time.

Figure 2 shows basic data on interest rate differentials, excluding and including the costs of reserve requirements for 18-month and 36-month loans, respectively, ${ }^{16}$ and private capital flows involving cash transactions or, simply, capital cash flows ${ }^{17}$ (a threemonth moving average has been included in the figure to show trends in the data). Panel A shows that major incentives for capital inflows were present from the second quarter of 1991 to mid-1992, from the third quarter of 1993 to the second quarter of 1995, from early 1996 to the second quarter of 1997 and, lastly, in the last quarter of 1998 and the first quarter of 1999.

It may be noted that, for 36-month loans, incentives to borrow declined after March 1994 and disappeared altogether once the August 1994 regulation was put in place. In fact, interest rate differentials became negative and incentives to borrow abroad were non-existent by mid-1995. The combined effects of these restrictive regulations and a faster devaluation of the nominal exchange rate explain the sudden interruption of capital flows experienced in the third quarter of 1995 (see section $\mathrm{B}$ of figure 2 ). The more flexible regulations introduced in early 1996, together with the appreciation of the nominal exchange rate, prompted a rapid increase in capital inflows in the second half of 1996. By late 1996, speculative attacks threatened to push the exchange rate below the floor of the currency band (as reflected by the peak in capital inflows observed in the data for December 1996). As discussed in section II, the government reacted to this capital surge by imposing an explicit (Tobin) tax in January 1997. The policy measures that followed in March and May of that year helped to neutralize capital inflows. Indeed, inflows remained stable until early 1999, when the Brazilian crisis triggered rapid capital outflows and generated strong devaluation pressures.

\section{IV}

\section{Determinants of private capital flows}

\section{A review of the existing literature}

A brief review of the existing literature on the effectiveness of price-based capital controls in Colombia provides a useful background for the additional econometric evidence presented below. The first attempt to study the determinants of capital flows following the liberalization policies adopted in 1993 was conducted by Cárdenas and Barrera (1997). Those authors argued that regulation was effective in shifting the composition of capital inflows towards longer-term maturities, but ineffective in reducing the volume of net flows. These arguments are based on three sets of findings. First, taking monthly data for the period January 1985 to June 1996, those authors found no relationship between capital flows and interest rate differentials when they used the tax equivalent of reserve requirements for short-term (18-month and 24-

\footnotetext{
${ }^{16}$ See equation 2.

${ }^{17}$ In Colombian terminology, these refer to flows that affect the foreign currency balance.
}

month) loans. ${ }^{18}$ Second, using dummy variables, they found signs of speculative behaviour before and after the regulations were changed. Lastly, they found that control variables had no permanent effects, as reflected by the insignificance of the coefficients for dummy variables covering the whole period for which specific controls were in place. The only exception was a dummy variable for the period January 1995-June 1996, which they interpreted as a "tequila effect".

As indicated by Villar and Rincón (2003), Cárdenas and Barrera (1997) found no evidence of a relationship between capital flows and the tax equivalent of reserve requirements because they failed to consider the effects of administrative controls prior to 1993. The effects of such controls and the regime change introduced in 1993 were analysed by Ocampo and Tovar (1997), employing monthly data for the period January 1990-December 1996. They concluded that controls on capital inflows

\footnotetext{
18 The formula used by Cárdenas and Barrera (1997) to measure the tax equivalent of reserve requirements is different from the one discussed in the previous section and is inaccurate.
} 
were effective in altering not only their term structure, but also the volume of net capital inflows. Unlike Cárdenas and Barrera (1997), they found evidence of interest arbitrage when they included the tax equivalent of reserve requirements for short-term loans (18 and 36 months). Furthermore, tests for the temporary effects of the different regulations, as reflected by dummy variables, suggested that external debt stock adjustments occurred after the February 1992 and September 1993 liberalization measures. They found evidence, too, of strong speculative behaviour prior to the August 1994 regulation (see the following section for an explanation), but also of a considerable though delayed effect of this policy change, which reduced capital inflows by a larger amount than the increases induced by the previous speculation. This result provides an alternative to Cárdenas and Barrera's "tequila effect" interpretation - i.e., that the capital controls introduced in August 1994 were effective, but with a lag. This interpretation seems reasonable, since spreads on sovereign bonds suggest that the Mexican crisis had only minor effects in Colombia. Also, aggregate net flows to Latin America suggest that contagion was significant only in the first quarter of $1995 .{ }^{19}$

In another paper, Rincón (1999) constructed an alternative measure of short-term monthly private capital flows to evaluate the effectiveness of capital controls. ${ }^{20}$ His results, based on cointegration analysis, provided evidence of the effectiveness of capital controls on financial inflows. In particular, he found a significant negative statistical relationship between the tax equivalent of reserve requirements, as measured by Ocampo and Tovar (1997), and capital flows. However, he did not control for stock adjustments associated with

\footnotetext{
${ }^{19}$ Cárdenas and Barrera (1997) and Ocampo and Tovar (1997) also examined whether interest rate arbitrage filtered through the service and trade accounts. The first study found evidence of filtering through the service account but not through the trade account; the second found no evidence of filtering in either case.

${ }^{20}$ This study uses monthly series constructed from quarterly balanceof-payments data, rather than the cash flow accounts of the central bank's foreign exchange balance, on which all the other studies are based. The major difference between the two is that they take different approaches to trade financing (see footnote 23 below). It should be pointed out that one disadvantage of balance-of-payments accounts is that they are only available on a quarterly basis, whereas figures 1 and 2 of the present paper indicate that monthly capital flows are highly volatile. This shows that the data-generating process cannot be adequately captured using quarterly data.
}

changes in regulations, which is a central issue of the debate on the effectiveness of capital controls (Cárdenas and Barrera, 1997; Ocampo and Tovar, 1997).

Cárdenas and Steiner (2000) analysed the determinants of private capital flows using quarterly data for the period 1987-1997. Their study used alternative measures of capital flows, which included, apart from the central bank's foreign exchange balance, estimates of capital flows filtered through non-factor service transactions. ${ }^{21}$ These measures were then used in two regressions of the determinants of capital flows. In the first, capital flows were regressed against a proxy for the external environment faced by the region (as reflected in the funds raised in international markets by Latin American countries). In the second, regressions were run against effective interest rate differentials, including the cost of reserve requirements under alternative maturities. ${ }^{22}$ Their findings suggested that capital flows were highly sensitive to the external environment, as well as to interest rate differentials, including the cost of reserve requirements. While they suggested that these results "should be interpreted as indirect evidence that Tobin taxes in Colombia not only affect the term structure of private capital inflows but also diminish their absolute amount", Cárdenas and Steiner (2000) hastened to point out that alternative exercises do not support this view.

In one of these alternative exercises, Cárdenas and Steiner ran OLS regressions for capital flows while controlling for interest rate differentials, excluding the cost of reserve requirements and the external environment variable. The effects of price-based capital account regulations were captured in this exercise by a dummy variable for the post-March 1993 period in which those regulations were in place. The results of this exercise indicated that capital flows were positively and significantly related to interest rate differentials and that they depended little on external factors, whether or not the post-March 1993 dummy was included. The effect of the dummy variable was significant in only one case, and in some cases the sign was positive, leading the authors to conclude " $[\ldots]$ that if Tobin taxes

\footnotetext{
${ }^{21}$ Three measures of private capital flows were used in this paper. The simplest was the capital account balance of the central bank's foreign exchange balance. The other two add, respectively, the "transitory" component of the private balance of non-factor services and the total balance of non-factor services.

${ }^{22}$ Maturities of 18, 24, 36 and 60 months were used.
} 
did in fact induce a decline in short-term foreign borrowing, they fostered an increase in overall foreign borrowing", indicating, furthermore, that "[t]his last point most probably has to do with the fact that while the Tobin taxes by definition reduce the interest rate differential [...] they might enhance the relative attractiveness of the country as a whole". However, this explanation suggests that the authors might be misinterpreting what the dummy is capturing. Indeed, if the attractiveness of the country is driving the result, the dummy is probably capturing something else, such as the "pull factors" associated with structural reforms. $^{23}$

Lastly, Villar and Rincón (2003) examined the effectiveness of capital controls from a different perspective. Their main concern was whether reserve requirements help authorities in open economies to manage the trade-off they face by enabling them, in particular, to avoid an excessive appreciation of the domestic currency while keeping control of domestic interest rates in order to discourage excess spending in the economy. In order to answer this question, they estimated reduced form equations for the period 19931999. These equations were derived from a partial equilibrium model aimed at analysing the joint determination of real interest rates and real exchange rates. Their model relied on three equations: one for the short-run determinants of the real interest rate, one for the long-run dynamics of the real exchange rate and one for the behaviour of capital flows. ${ }^{24}$

Their econometric estimates and simulations indicated that price-based controls on capital inflows had a positive effect on domestic ex-ante real interest rates and, therefore, that controls were effective in increasing "[...] domestic real interest rates in a context of an open economy with a low degree of monetary autonomy". They also found that the controls produced this effect without creating pressure for a real appreciation of the peso.

\section{Econometric framework}

As discussed in the preceding sections, the uncovered interest rate differential approach provides a suitable framework for studying the effects of Colombia's regulation of capital flows. Indeed, using monthly data for the period January 1990-December 1999, it is possible to estimate an equation in which private capital flows, as measured by the central bank's foreign exchange balance, ${ }^{25}$ are a function of interest rate differentials and other variables. In other words, it can be assumed that there is a portfolio allocation problem that yields a (linear) solution of the following type:

$$
K f=K f\left(g, A, \delta_{i}, \phi_{i}\right)
$$

where $g$ is assumed to be an economic activity variable, proxied by imports of capital goods; $A$ is the interest rate differential arbitrage factor, including the effects of reserve requirements on foreign borrowing, as defined by equation 2 and graphed in figure $2 ; \delta_{i}$ represents the dummy used to control for the effect on total volume of the different regulations enforced during the period of analysis; ${ }^{26}$ and $\phi_{i}$ represents the dummies

\footnotetext{
${ }^{23}$ Explanations for capital flows to developing countries have focused on two main factors: "push" and "pull" factors. The first are factors that operate by reducing the attractiveness of capital flows to industrialized countries. The second are factors that attract capital as a result of improvements in the risk/return characteristics of assets issued by developing countries. Lastly, a third factor could be associated with a change in the degree of financial integration due to regulatory changes (see Agénor and Montiel, 1999).

${ }^{24}$ The interest rate is determined by expected real devaluation, the tax equivalent of reserve requirements and the international ex-ante interest rate. Short-run deviations from the long-run parity condition are presumed to be associated with excess domestic money supply. The exchange rate is determined, by long-run real factors, such as the terms of trade, government expenditure, real capital flows and a trend capturing productivity and technological changes. Lastly, capital flows are modelled as a function of the interest rate differentials, including the tax equivalent of reserve requirements.
}

\footnotetext{
${ }^{25}$ This measure of cash capital flows differs from normal balanceof-payments accounts in that exports and imports are registered at the time when they are actually paid for, which is when they actually generate a cash flow. Accordingly, trade financing is excluded from the capital account and is treated as a determinant of the current account of the foreign exchange balance. In any case, it is correct to exclude trade financing from the current exercise, since the regulations pertaining to it were different and were only partly subject to reserve requirements. Also, Ocampo and Tovar (1997) found no evidence of interest rate arbitrage in trade financing.

${ }^{26}$ Other variables used in the literature include credit ratings or measures of excess expenditure to capture determinants of current account deficits. Although it may be desirable to control for these, the way such series have been constructed makes them unsuitable. Indeed, authors such as De Gregorio, Edwards and Valdés (2000) or Rincón (1999) have constructed monthly series from annual or quarterly series, which can easily result in biased estimates.
} 
used to control for temporary changes in the supply of capital flows associated with the tequila, Asian, Russian and Brazilian crises. ${ }^{27}$

The signs in equation 7 show the expected relationship between private capital flows and each of the explanatory variables. However, the interpretation of the dummies for capital controls depends on whether the regulations liberalized the capital account (i.e., in February 1992, September 1993, February-March 1996, March 1997 and January and September 1998) or tightened the controls (i.e., in March and August 1994, January 1997 and May 1997; see table 1). ${ }^{28}$ A positive coefficient is expected in the first case, and should be interpreted as an adjustment in stocks of debt induced by liberalization. Meanwhile, a negative coefficient is expected in the latter case, reflecting the discrete effect of controls on capital inflows that generate effects beyond those captured in the interest rate differential $(A)$.

The interpretation of the dummies used for the period August 1994-January 1996 warrants special attention. In the weeks preceding the adoption of tighter measures in August 1994, the central bank received registrations for significant amounts of debt (which were subject to the reserve requirements decreed in March 1994), as agents expected that the new President, who took office in early August, would propose more stringent regulations to the central bank, which were likely to be accepted. Without a doubt, these early registrations reduced the effectiveness of controls for some months after the new restrictions were introduced. In order to reflect this speculative attack and to measure the effectiveness of controls during this period, two dummies were used. The first, for September-December 1994, was meant to capture the speculative attack against controls, and should thus have a positive sign, while a dummy for January 1995-January 1996 captured the delayed effect of controls, and should have a negative sign.

\footnotetext{
${ }^{27}$ The dummies included were: tequila (January 1995-March 1995), Asia (November 1997-December 1997), Russia (August 1998November 1998) and Brazil (January 1999-May 1999). Additionally, an overall dummy for November 1997-November 1999 was included, as it is assumed that some financial flows turned away from emerging economies after the Asian crisis. Only the dummies that were statistically significant are reported.

${ }^{28}$ A dummy variable was also included to capture the extraordinary inflows of December 1996, which were partly associated with privatization processes.
}

Equation 7 captures the effect of the new regulations through two different channels. First, through the additional cost of foreign borrowing, which affects capital flows through the arbitrage factor and second, through the discrete effects of regulations estimated using the dummy variables. The latter effect may be interpreted as evidence of imperfect substitution between loans of different maturities due to risk factors on the supply side that affect their relative availability.

\section{Cointegration analysis}

In order to estimate equation 7, the series $K f, g$ and $A$ were tested for the order of integration. Following the approach used by Cárdenas and Barrera (1997) and Ocampo and Tovar (1997), two alternative measures for the interest arbitrage factor were used; one is constructed using the cost of reserve requirements for 18-month loans, while the other uses 36-month loans (see figure 2). Augmented DickeyFuller tests for the presence of unit roots are reported in table 2. As shown, it was not possible to reject the null hypothesis of the presence of unit roots for any of the four series.

Owing to the existence of unit roots in the data and in order to avoid spurious regressions, the econometric estimates were performed using a multivariate framework. ${ }^{29}$ More specifically, Johansen's maximum likelihood cointegration analysis framework was employed to estimate the linear relationship described by equation 7 . In particular, the relationship estimated is:

$$
\Delta z_{t}=\Gamma_{1} \Delta z_{t-1}+\Pi z_{t-1}+\mu+\Psi D_{t}+\varepsilon_{t}
$$

where, $\Pi=\alpha \beta$ ' provided that $\alpha$ and $\beta$ are (3x1) matrices that measure the speed of adjustment to disequilibrium and the long-run coefficients or cointegration relationship, respectively. Meanwhile, $z_{t}$ is a $(3 \times 1)$ vector formed by the variables $K f$, $A$ and $g$, and $D_{\mathrm{t}}$ is a vector formed by the intervention dummies $\delta_{i}$ and $\phi_{i}$ that control for changes in regulations on foreign borrowing and for supply shocks associated with the

\footnotetext{
${ }^{29}$ Indeed, it is well known that a linear combination of non-stationary variables may be stationary and therefore cointegrated. As suggested in the literature, the correct way to proceed is to use a multivariate analysis and test for the presence of cointegration vectors.
} 
Colombia: Augmented dickey-fuller tests of unit roots ${ }^{a}$

\begin{tabular}{|c|c|c|c|c|c|c|c|c|c|c|c|}
\hline \multirow[b]{3}{*}{ VARIABLE } & \multirow[b]{3}{*}{$\begin{array}{l}\text { Lag } \\
\text { length }\end{array}$} & \multicolumn{10}{|c|}{ T-STATISTIC } \\
\hline & & \multicolumn{2}{|c|}{ T-tao } & \multicolumn{2}{|c|}{3} & \multicolumn{2}{|c|}{$\mathrm{T}-\mathrm{mu}$} & \multicolumn{2}{|c|}{1} & \multicolumn{2}{|c|}{$\mathrm{T}$} \\
\hline & & $\begin{array}{l}\text { Coef- } \\
\text { ficient }\end{array}$ & $\begin{array}{l}\text { Critical } \\
\text { value }\end{array}$ & $\begin{array}{l}\text { Coef- } \\
\text { ficient }\end{array}$ & $\begin{array}{c}\text { Critical } \\
\text { value }\end{array}$ & $\begin{array}{l}\text { Coef- } \\
\text { ficient }\end{array}$ & $\begin{array}{l}\text { Critical } \\
\text { value }\end{array}$ & $\begin{array}{l}\text { Coef- } \\
\text { ficient }\end{array}$ & $\begin{array}{c}\text { Critical } \\
\text { value }\end{array}$ & $\begin{array}{l}\text { Coef- } \\
\text { ficient }\end{array}$ & $\begin{array}{c}\text { Critical } \\
\text { value }\end{array}$ \\
\hline Cash capital flows ${ }^{b}$ & 3 & -2.24 & -3.45 & 2.72 & 6.49 & -2.32 & -2.89 & 2.71 & 4.71 & -1.89 & -1.95 \\
\hline Diff [Cash capital flows] & 2 & -10.35 & -3.45 & & & & & & & & \\
\hline \multicolumn{12}{|l|}{ Interest rate differentials } \\
\hline 36-month credits $(\mathrm{A} 36)^{\mathrm{b}}$ & 6 & -3.08 & -3.45 & 5.32 & 6.49 & -1.79 & -2.89 & 1.68 & 4.71 & -1.64 & -1.95 \\
\hline $\operatorname{Diff}[\mathrm{A} 36]$ & 3 & -4.84 & -3.45 & & & & & & & & \\
\hline 18 -month credits $(\mathrm{A} 18)^{\mathrm{b}}$ & 6 & -2.75 & -3.45 & 4.06 & 6.49 & -1.64 & -2.89 & 1.42 & 4.71 & -1.69 & -1.95 \\
\hline Diff $[$ A18 ] & 3 & -4.84 & -3.45 & & & & & & & & \\
\hline Imports of capital goods ${ }^{b}$ & 2 & -1.40 & -3.45 & 1.16 & 6.49 & -0.92 & -2.89 & -1.38 & 4.71 & 0.04 & -1.95 \\
\hline $\begin{array}{l}\text { Diff [ Imports of } \\
\text { capital goods] }\end{array}$ & 1 & -11.66 & -3.45 & & & & & & & & \\
\hline
\end{tabular}

Source: Prepared by the authors.

a Indicates that the null hypothesis of presence of unit root cannot be rejected.

b Diff [...] denotes first difference of the variable.

Critical values from Dickey and Fuller (1981), as reproduced in Harris (1995), for a sample size of T=100 and 5\% significance level.

Lag lengths for the test were chosen using the BIC information criterion.

international financial environment, respectively. ${ }^{30}$ Lastly, $\varepsilon_{t} \sim \operatorname{niid}(O, \Sigma){ }^{31}$

The results are summarized in tables 3 and 4 . Table 3 reports the $\lambda$-trace and $\lambda$-max tests for the reduced rank hypothesis in the full VAR model. ${ }^{32}$ The first three equations in this table make use of interest rate differentials, including the cost of reserve requirements for 36-month loans, while the remaining equations (4 to 6) use the cost of reserve requirements for 18-month loans. According to these tests, one cointegration relationship was found between private capital flows $(K f)$, interest rate differentials $(A)$ and imports of capital goods $(g)$ in each of the different equations estimated. For interpretation purposes, the cointegration vector or long-run relationship is normalized by the coefficient

\footnotetext{
${ }^{30}$ It may appear to some readers that many dummies imply uncertainty about the specification of the model. However, this is not a universally shared view and is probably not shared by British econometricians such as David Hendry. We thank Ken West for pointing this out.

${ }^{31}$ See appendix for a more detailed derivation of the system estimated.

32 The lag lengths for the unrestricted VAR models were all chosen using the BIC information criterion. Moreover, as shown in the appendix, the VECM estimates use this number of lags minus one.
}

associated with capital flows, so that the relevant equation for capital flows becomes:

$$
\begin{aligned}
& \text { [9] } \Delta K f_{t}=\Gamma_{11} \Delta K f_{t-1}+\Gamma_{12} \Delta A_{t-1}+\Gamma_{13} \Delta g_{t-1} \\
& +\tilde{\alpha}_{1}\left(K f_{t-1}+\left[\left(\frac{\beta_{2}}{\beta_{1}}\right) \mathrm{A}_{t-1}+\left(\frac{\beta_{3}}{\beta_{1}}\right) \mathrm{g}_{t-1}\right]\right)+\Psi_{11} D_{t}+\varepsilon_{t}
\end{aligned}
$$

where $\tilde{\alpha}_{1}=\alpha_{1} \beta_{1}$ measures the average speed of adjustment to long-run equilibrium (see appendix for more details).

Estimates for equation 9 are reported in table 4, columns 1, 2, 4 and 5. At first glance, the estimates suggest a strong and statistically significant relationship between cash capital flows and interest rate differentials; ${ }^{33}$ however, this will be analysed in more detail later. Also, the parameters of the error correction mechanism term, $\tilde{\alpha}_{1}$, indicate that disequilibria in the

\footnotetext{
${ }^{33}$ The effects are also as expected-i.e., increases in both the activity variable and the interest rate differential tend to increase capital flows. Nonetheless, because of the way long-run cointegration relations are usually specified (i.e., in vector notation), the signs show up as negative in table 4.
} 
TABLE 3

Colombia: Rank test for cointegration vectors ${ }^{a}$

\begin{tabular}{|c|c|c|c|c|c|c|c|}
\hline & \multirow[t]{2}{*}{ Eigen value } & \multirow[t]{2}{*}{ L-max } & \multirow[t]{2}{*}{ Critical value } & \multirow[t]{2}{*}{ L-trace } & \multirow[t]{2}{*}{ Critical value } & \multicolumn{2}{|c|}{ Ho: } \\
\hline & & & & & & $\mathrm{b}$ & c \\
\hline \multirow[t]{3}{*}{ Equation 1} & 0.4194 & 64.2 & $21.0^{\mathrm{d}}$ & 77.2 & $29.7^{\mathrm{d}}$ & $r=0$ & $\mathrm{p}-\mathrm{r}=3$ \\
\hline & 0.0635 & 7.8 & 14.1 & 13.0 & 15.4 & $r=1$ & $\mathrm{p}-\mathrm{r}=2$ \\
\hline & 0.0434 & 5.2 & 3.8 & 5.2 & 3.8 & $r=2$ & $\mathrm{p}-\mathrm{r}=1$ \\
\hline \multirow[t]{3}{*}{ Equation 2} & 0.4145 & 63.2 & $21.0^{\mathrm{d}}$ & 72.8 & $29.7^{\mathrm{d}}$ & $r=0$ & $\mathrm{p}-\mathrm{r}=3$ \\
\hline & 0.0636 & 7.8 & 14.1 & 9.6 & 15.4 & $r=1$ & $\mathrm{p}-\mathrm{r}=2$ \\
\hline & 0.0159 & 1.9 & 3.8 & 1.9 & 3.8 & $r=2$ & $\mathrm{p}-\mathrm{r}=1$ \\
\hline Equation $3^{\mathrm{e}}$ & 0.4105 & 62.4 & $21.0^{\mathrm{d}}$ & 62.4 & $29.7^{\mathrm{d}}$ & $r=0$ & $\mathrm{p}-\mathrm{r}=1$ \\
\hline \multirow[t]{3}{*}{ Equation 4} & 0.4072 & 61.7 & $21.0^{\mathrm{d}}$ & 74.3 & $29.7^{\mathrm{d}}$ & $r=0$ & $\mathrm{p}-\mathrm{r}=3$ \\
\hline & 0.0754 & 9.3 & 14.1 & 12.6 & 15.4 & $r=1$ & $p-r=2$ \\
\hline & 0.0279 & 3.3 & 3.8 & 3.3 & 3.8 & $r=2$ & $\mathrm{p}-\mathrm{r}=1$ \\
\hline \multirow[t]{3}{*}{ Equation 5} & 0.3990 & 60.1 & $21.0^{\mathrm{d}}$ & 70.9 & $29.7^{\mathrm{d}}$ & $r=0$ & $\mathrm{p}-\mathrm{r}=3$ \\
\hline & 0.0783 & 9.6 & 14.1 & 10.8 & 15.4 & $r=1$ & $\mathrm{p}-\mathrm{r}=2$ \\
\hline & 0.0102 & 1.2 & 3.8 & 1.2 & 3.8 & $r=2$ & $\mathrm{p}-\mathrm{r}=1$ \\
\hline Equation $6^{\mathrm{e}}$ & 0.3969 & 59.7 & $21.0^{\mathrm{d}}$ & 59.7 & $29.7^{\mathrm{d}}$ & $r=0$ & $\mathrm{p}-\mathrm{r}=1$ \\
\hline
\end{tabular}

Source: Prepared by the authors.

a Cointegration vectors are presented in table 4. Critical values from Osterwald-Lenum (1992) as reproduced in Harris (1995). Lags in all Var-models: 2. Number of observations: 116.

b Number of cointegration vectors.

c Number of unit roots in the system.

d Indicates rejection of null hypothesis at 5\% statistical significance level.

e Equation conditioned by weak exogeneity. See table 4 for more details.

long-run relationship are rapidly and exclusively adjusted by cash capital flows. In fact, the numerical and statistical insignificance of the coefficients associated with interest rate differentials and imports of capital goods in the error correction mechanism in the first five equations in table 4 suggests that these two variables could be treated as weakly exogenous to the system. With this in mind, a likelihood ratio test on the loadings for these variables was performed. ${ }^{34}$ Also, a complementary likelihood ratio test for the exclusion of interest rate differentials and imports of capital goods from the cointegration vector was performed. The results of both tests are reported in the lower part of table 4 . The first test confirms the initial view that it is necessary to estimate a conditioned model for capital

${ }^{34}$ See appendix for further details regarding this test. inflows - i.e., that interest rate differentials and imports of capital goods should be modeled as weakly exogenous variables. However, the second test indicates that these variables cannot be excluded from the cointegration vector. ${ }^{35}$

Given these results, the new system conditioned by weak exogeneity becomes:

$$
\begin{gathered}
\quad \Delta K f_{t}=\tilde{\Gamma}_{0} \Delta A_{t}+\tilde{\Gamma}_{0} \Delta g_{t}+\tilde{\Gamma}_{1} \Delta Z_{t-1} \\
+\tilde{\alpha}_{1}\left(K f_{t-1}+\left[\left(\frac{\beta_{2}}{\beta_{1}}\right) \mathrm{A}_{t-1}+\left(\frac{\beta_{3}}{\beta_{1}}\right) \mathrm{g}_{t-1}\right]\right)+\Psi_{11} D_{t}+\varepsilon_{t}
\end{gathered}
$$

\footnotetext{
${ }^{35} \mathrm{~A}$ joint test for both restrictions on the cointegration vector and weak exogeneity is also reported in table 4 . As indicated, the null hypothesis for joint restrictions was rejected.
} 


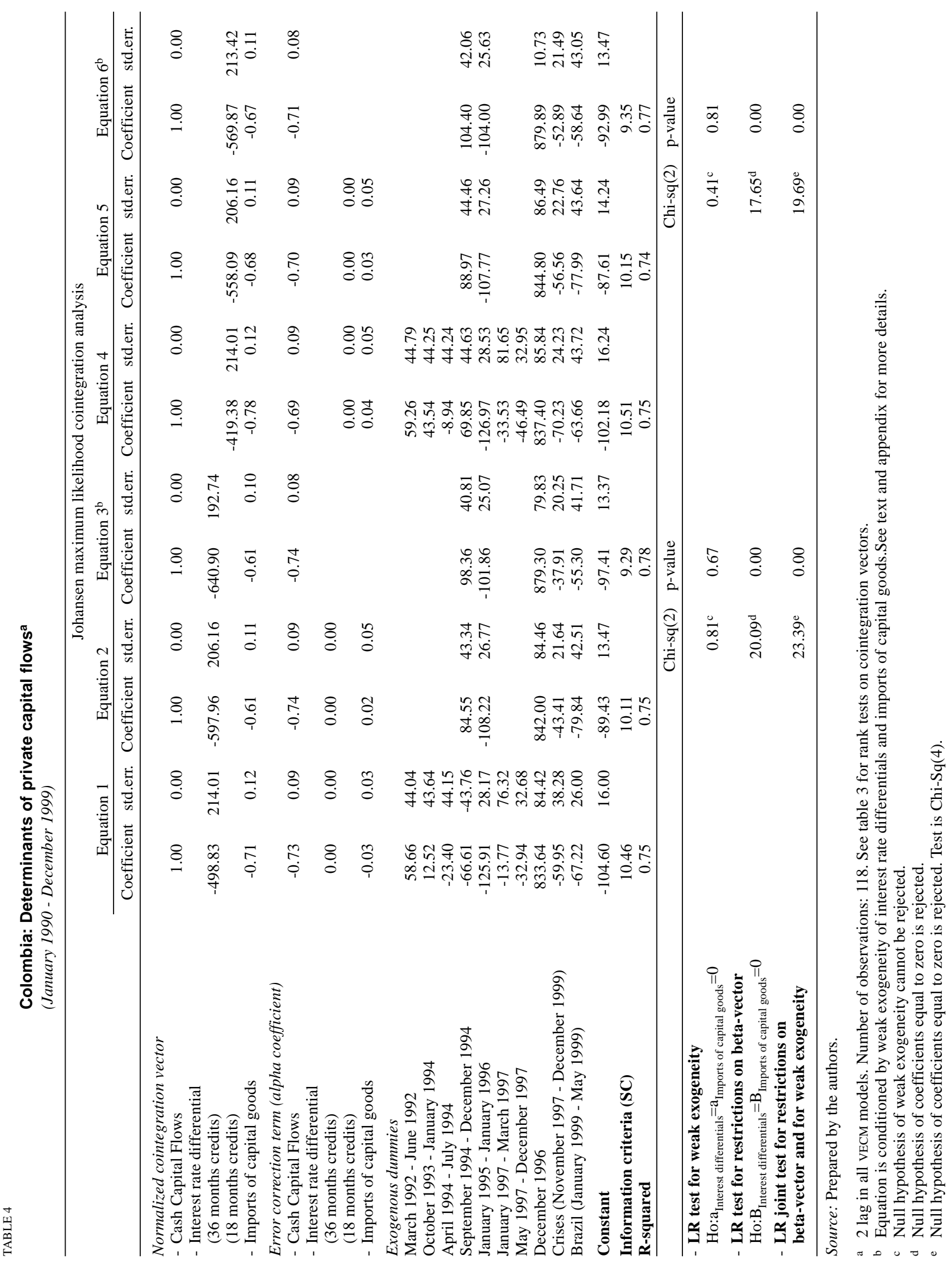


The estimates for the conditioned models using the two alternative measures for the interest rate differentials are reported as equations 3 and 6 in table 4 . According to these equations, over $70 \%$ of the longrun disequilibrium is adjusted with a one-month lag, indicating that regulations on capital inflows, which alter the long-run equilibrium by inducing changes in interest rate differentials, will have a rapid effect on the dynamics of cash capital flows. These results also indicate that interest rate differentials Granger-cause capital flows. Therefore, more restrictive regulations will trigger a strong and immediate contraction of capital inflows. This indicates, in turn, that price-based controls on capital inflows rapidly reduce pressures on fundamental macroeconomic variables.

In addition to the estimates, a test for the constancy of the long-run parameters was performed. The plot of the test for the constancy of the cointegration space between September 1993 and December 1999 is reported in figure 3 . According to the test, which was scaled by the $95 \%$ quantile in the $\chi^{2}$-distribution so that unity corresponds to a test with a 5\% significance level, it was not possible to reject the null hypothesis of parameter constancy for the period investigated for either equation 3 or equation 6 in table 4 (see appendix). In this regard, an important related question is whether the sensitivity of cash capital flows to interest rate differentials increased following the September 1993 liberalization. In fact, Ocampo and Tovar (1997) found evidence pointing in this direction. However, for the sake of exposition, we will return to this issue in a later section. For now, it is enough to note that despite the possibility of a structural change in the long-run relationship, the test for parameter constancy indicates that that relationship was statistically stable in the postSeptember 1993 period.

The estimated effects of interest rate differentials on capital flows and the net effect attributable to reserve requirements are reported in table 5. Using the longrun coefficient for interest rate differentials associated with 36-month loans (equation 3), it is shown that capital inflows would have been significantly higher in the absence of controls. The effect of controls was particularly marked between April and August 1994 (capital flows were reduced on average by US\$ 73 million per month), between September 1994 and January 1996 (US\$ 102 million per month) and from January to March 1997 (US\$ 70 million per month).

As shown by the error correction mechanism estimates, the price effect of controls on the volume of financial flows will tend to disappear quite rapidly.
Therefore, it is necessary to examine other channels through which controls may affect the volume of capital inflows. The exogenous dummies in table 4 capture the discrete effects of policy changes in regulations. The results show that stock adjustments appear to have followed the February 1992 and September 1993 liberalization reforms, but the findings in this regard were not conclusive (see equations 1 and 4 in table 4).

The estimates also suggest that there was speculative behaviour prior to the shift to a tighter policy stance in August 1994, which had the undesirable effect of increasing capital inflows over the following four months (by an average of more than US\$ 98 million per month). In any case, this policy change had a delayed effect, as reflected by the reduction of capital inflows by over US\$ 101 million per month between January 1995 and January 1996. Therefore, the net discrete effect of these particular regulations was a reduction of capital inflows by over US\$ 921 million over the 17 months it was in place; i.e., between August 1994 and January 1996. Furthermore, if the discrete effects of the August 1994 change are added to those induced by the higher cost of foreign borrowing (as calculated in table 5), then the net effect of reserve requirements was far from negligible: US\$ 2.2 billion for the whole period for which this regulation was in place - a reduction equivalent to $27 \%$ of the international reserves held at the central bank in December 1995.

Other regulations that had some discrete effects were those introduced in January 1997, when the explicit Tobin tax was put in place, and in May 1997. However, these effects are statistically insignificant.

The estimates also controlled for discrete changes associated with international financial crises. ${ }^{36}$ Interestingly, a dummy for the period November 1997 December 1999 as a whole, which controls for the supply effect associated with the international financial disturbances, is statistically significant and has nonnegligible effects. Indeed, estimates suggest that, on average, monthly capital inflows fell by US $\$ 38$ million. Estimates also show an adverse and significant "neighbourhood" effect associated with the Brazilian crisis, which reduced monthly cash capital inflows by more than US\$ 55 million between January and May 1999.

\footnotetext{
${ }^{36}$ An attempt was made to use Latin bond indexes to capture the international financial environment, but no satisfactory results were obtained.
} 
CEPAL REVIEW 81. DECEMBER 20003

23

FIGURE 3

Colombia: Test for constancy of the cointegration space

A. For cointegration equation estimates using 36-month credits (equation 3 in table 4)

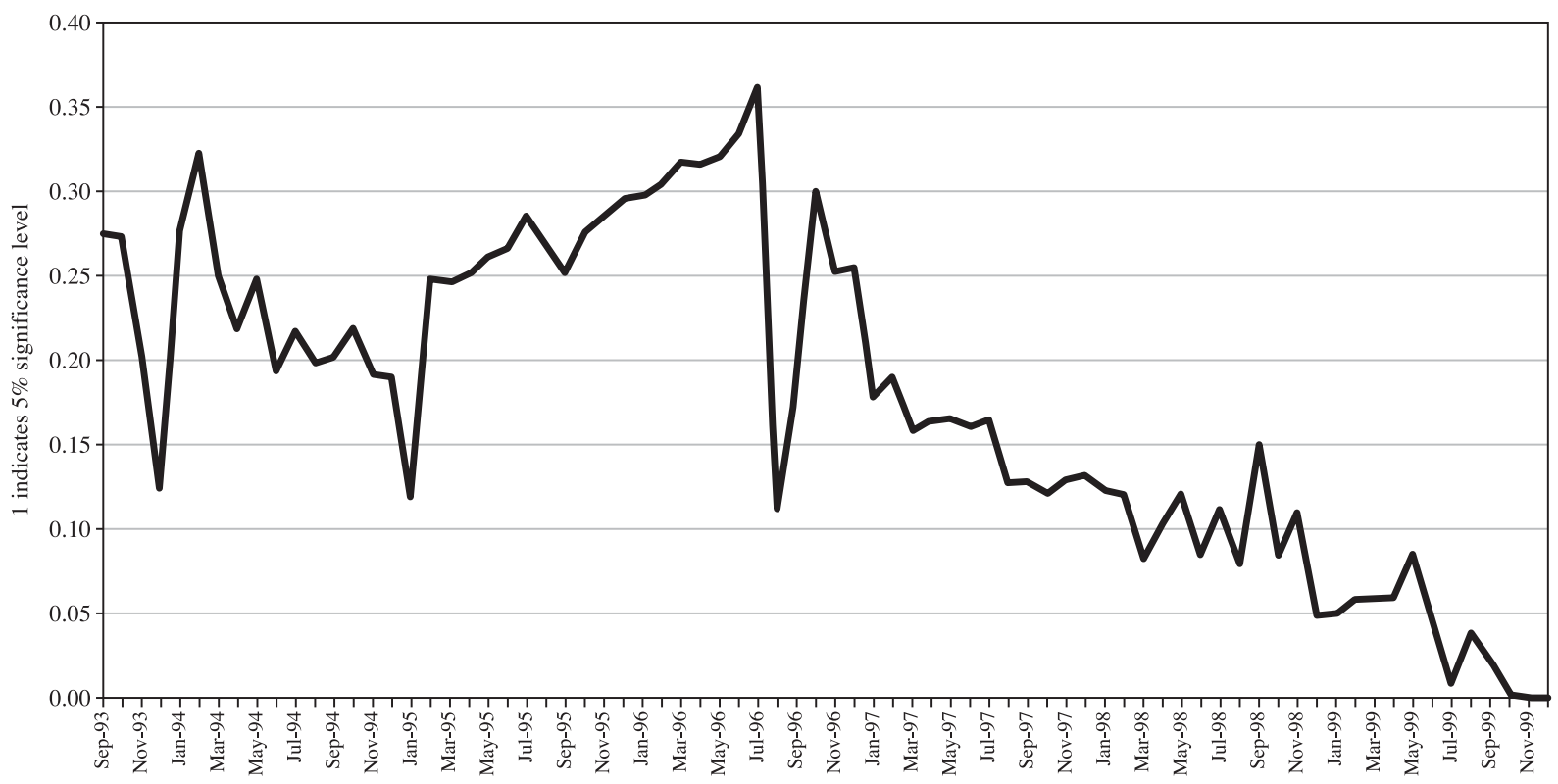

A. For cointegration equation estimates using 18 -month credits $^{\mathrm{a}}$ (equation 6 in table 4)

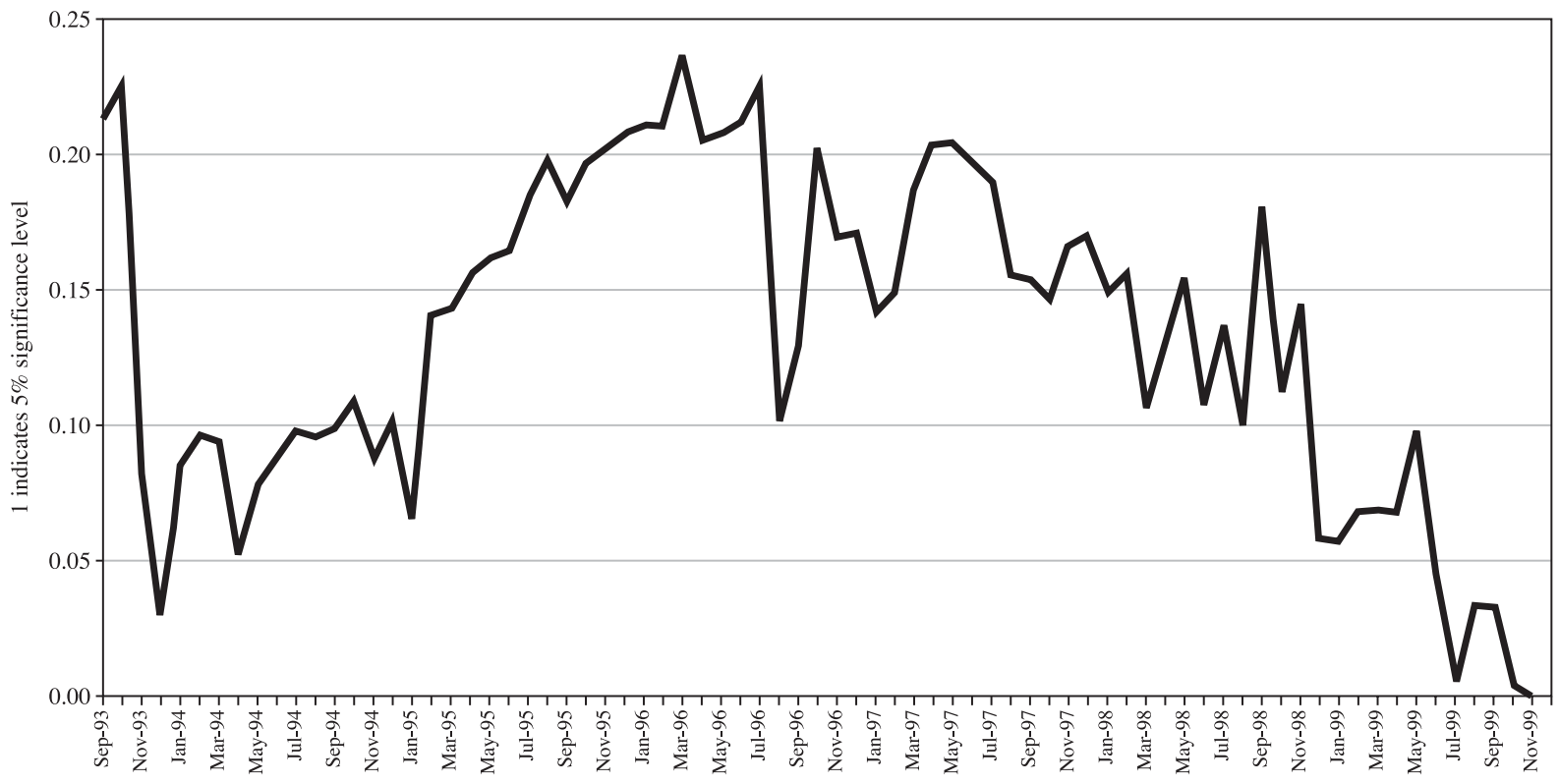

Source: Calculations based on data from the Central Bank of Colombia (Bunco de la República).

a Test statistic has been scaled by the $95 \%$ quartile in the chi-sq. distribution so that unity corresponds to a test with $5 \%$ significance level.

COLOMBIA'S EXPERIENCE WITH RESERVE REQUIREMENTS ON CAPITAL INFLOWS - JOSE A. OCAMPO AND CAMILO E. TOVAR 
TABLE 5

Colombia: Estimated effects of interest rate differentials on cash capital flows

(Monthly averages)

\begin{tabular}{|c|c|c|c|c|c|c|c|c|c|}
\hline & \multicolumn{3}{|c|}{$\begin{array}{l}\text { Interest rate differentials } \\
\quad \text { (percentages) }\end{array}$} & \multicolumn{3}{|c|}{$\begin{array}{l}\text { Estimated cash capital flows } \\
\text { using the estimated cointegration vector }{ }^{\mathrm{a}} \\
\text { (Millions of United States dollars) }\end{array}$} & \multicolumn{3}{|c|}{$\begin{array}{l}\text { Estimated cash capital flows } \\
\text { using the Kalman filter estimates } \\
\text { (Millions of United States dollars) }\end{array}$} \\
\hline & $\begin{array}{l}\text { Excluding } \\
\text { reserve } \\
\text { require- } \\
\text { ments }\end{array}$ & $\begin{array}{l}\text { Including } \\
\text { reserve } \\
\text { require- } \\
\text { ments }\end{array}$ & $\begin{array}{l}\text { Net } \\
\text { effect } \\
\text { require- } \\
\text { ments }\end{array}$ & $\begin{array}{l}\text { Excluding } \\
\text { reserve } \\
\text { require- } \\
\text { ments }\end{array}$ & $\begin{array}{l}\text { Including } \\
\text { reserve } \\
\text { require- } \\
\text { ments }\end{array}$ & $\begin{array}{l}\text { Net } \\
\text { effect } \\
\text { require- } \\
\text { ments }\end{array}$ & $\begin{array}{l}\text { Excluding } \\
\text { reserve } \\
\text { require- } \\
\text { ments }\end{array}$ & $\begin{array}{l}\text { Including } \\
\text { reserve } \\
\text { require- } \\
\text { ments }\end{array}$ & $\begin{array}{c}\text { Net } \\
\text { effect } \\
\text { require- } \\
\text { ments }\end{array}$ \\
\hline January 1990 - February 1992 & 7.3 & & & 46.5 & & & 4.5 & & \\
\hline March 1992 - September 1993 & 9.3 & & & 59.4 & & & 24.9 & & \\
\hline October 1993 - March 1994 & 13.7 & 9.8 & 3.9 & 87.9 & 62.7 & 25.1 & 53.2 & 37.8 & 15.4 \\
\hline April 1994 - August 1994 & 18.6 & 7.3 & 11.3 & 119.2 & 46.7 & 72.5 & 76.0 & 22.4 & 53.6 \\
\hline September 1994 - January 1996 & 15.2 & -0.8 & 16.0 & 97.5 & -4.8 & 102.3 & 63.7 & -5.7 & 69.4 \\
\hline February 1996 - December 1996 & 15.5 & 6.4 & 9.2 & 99.6 & 40.7 & 58.9 & 98.5 & 43.9 & 54.6 \\
\hline January 1997 - March 1997 & 14.4 & 3.5 & 10.9 & 92.2 & 22.6 & 69.6 & 124.5 & 30.2 & 94.3 \\
\hline April 1997 - May 1997 & 11.0 & 4.2 & 6.8 & 70.5 & 27.0 & 43.5 & 91.9 & 35.9 & 56.0 \\
\hline June 1997 - December 1997 & -1.3 & -6.0 & 4.7 & -8.3 & -38.2 & 29.9 & -7.9 & -52.2 & 44.3 \\
\hline January 1998 - September 1998 & 4.3 & -0.4 & 4.7 & 27.8 & -2.2 & 30.0 & 27.4 & -3.0 & 30.4 \\
\hline November 1998 - December 1999 & -1.1 & -3.7 & 2.7 & -6.9 & -24.0 & 17.1 & -8.0 & -33.7 & 25.7 \\
\hline
\end{tabular}

Source: Prepared by the authors.

a Estimates based on equation 3 of table 4 .

Therefore, since late 1997 net capital inflows to the Colombian economy were reduced by nearly US $\$ 807$ million as a result of international contagion.

\section{Temporary and discrete effects of interest rate differentials}

As an alternative exercise to estimate the effects of capital flow controls, a Kalman filter was applied to equation 7 . Figure 4 graphically displays the temporary and discrete effects of interest rate differentials on capital flows for 36-month loans (panel A). The former are associated with changes in interest rate differentials due to variations in the cost of reserve requirements, while the latter are associated with adjustments in the volume of capital flows. As shown, regulations were effective in reducing capital inflows when they were tightened, particularly in August 1994, January 1997 and May 1997. In turn, capital flows increased when regulations were loosened in February 1996 and January 1998. As shown in panel B of figure 4 , which compares the estimated effects of interest rate differentials including and excluding the cost of reserve requirements, the effect of interest rate differentials on capital flows is mainly attributable to capital controls, since the difference between the two series is mainly attributable to the cost of reserve requirements.

Furthermore, the estimated effects of interest rate differentials using the Kalman filter methodology follow a dynamic parallel to the one estimated using the Johansen cointegration framework (see table 5). However, it is worth mentioning that prior to January 1997 the net effects of reserve requirements appear weaker with the Kalman filter than with the cointegration methodology and slightly stronger after that date.

These results indicate that controls on capital flows were effective in reducing the volume of these inflows, owing both to the increased cost of shorter-term borrowing and to the discrete effects of the regulations, associated with the imperfect substitution of borrowing at different maturities. In particular, the strict controls imposed in August 1994 (with a lag related to the speculative behaviour observed before the regulations 
FIGURE 4

\section{Colombia: Estimated effects of price-based capital controls on cash capital flows}

A. Temporary and discrete effects of interest rate differentials (including costs of forced deposits)

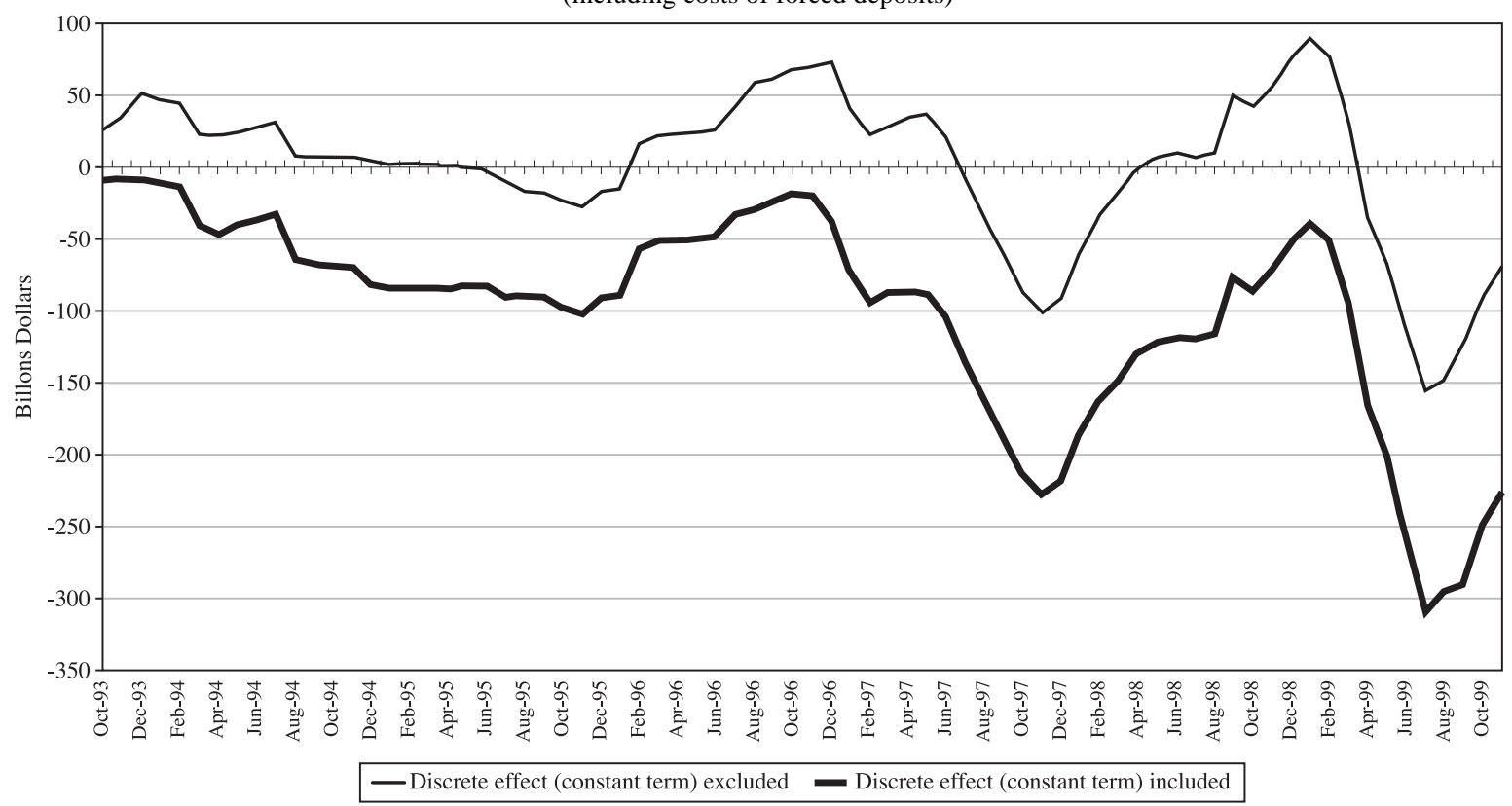

B. Overall effects of interest rate differentials (excluding and including costs of reserve requirements)

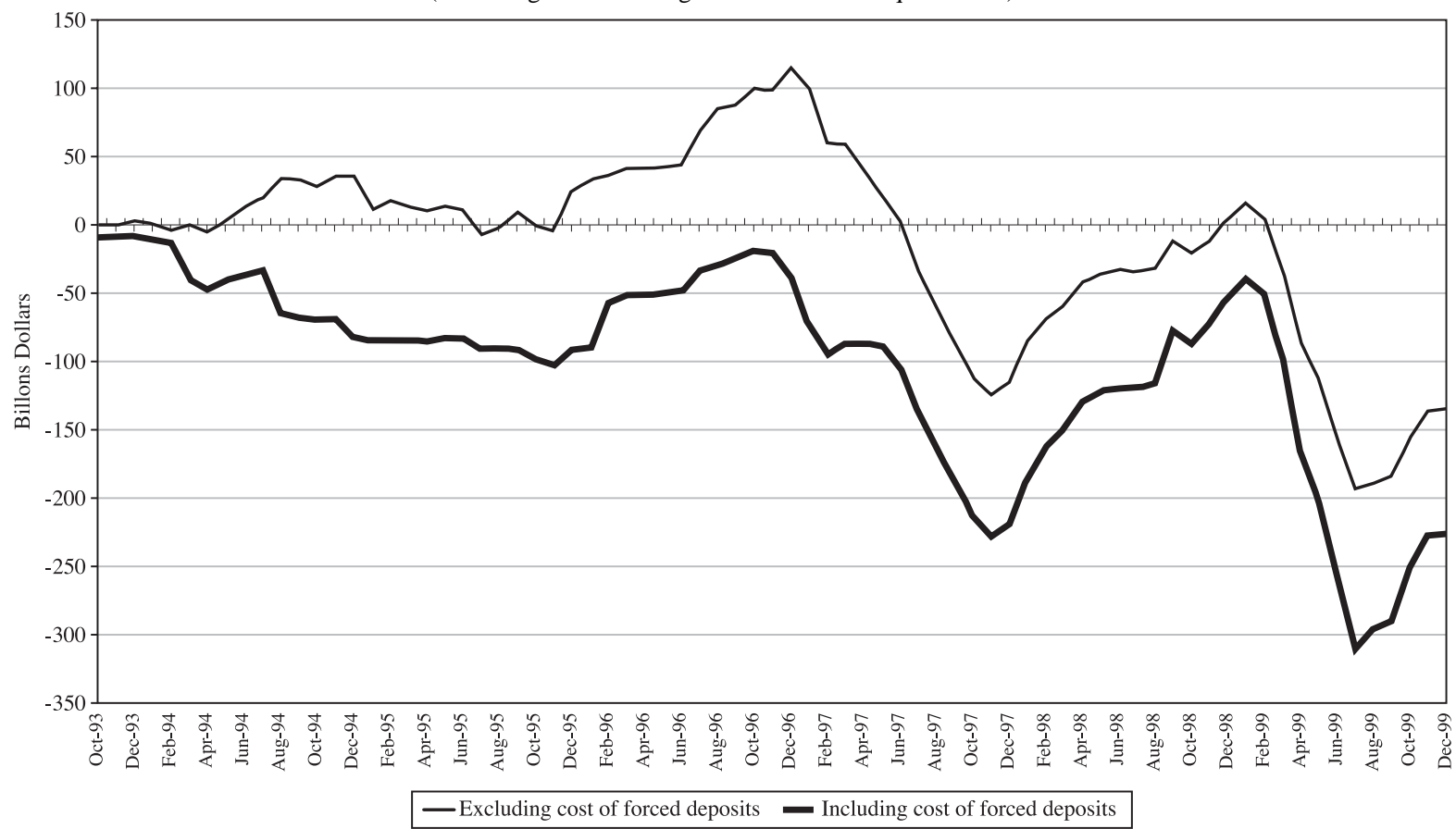

Source: Calculations based on data from the Central Bank of Colombia (Banco de la República). 
were introduced) and the January and May 1997 restrictions had the desired effects. The results also indicate that temporary adjustments in the volume of net capital flows may have taken place following the February 1992 and September 1993 liberalization measures.

\section{Testing for structural change}

An important issue regarding price-based capital controls is that they are designed for countries that choose to be integrated in international capital markets. Therefore, whether the transition from old-style exchange controls to price-based capital account regulations effectively liberated of the capital account constitutes a central question to be addressed. Or, to put it differently, an effective liberalization should reflect an increased sensitivity of cash capital flows to interest arbitrage incentives. Table 6 presents the results of a simple OLS regression analysis ${ }^{37}$ conducted to capture the change in the sensitivity of cash capital flows to interest arbitrage following the September 1993 reform of the capital account regime. The main difference between this exercise and the cointegration procedure reported above is that although both measures of interest rate differentials are interacted with two dummy variables, one of them captures the preliberalization period (January 1990-September 1993) and the other, the post-liberalization period (October 1993-December 1999).

Table 6 reports six different regressions. The main differences between them lie in the interest rate differentials used; i.e., 18-month or 36-month credits. Furthermore, in each case three different exercises are reported. Equations 1 and 2 report simple regressions without controlling for changes in the volume of net capital flows associated with policy shifts or with the international environment after the financial crises. The remaining equations report different specifications that do control for these factors. In addition, for each regression a Chow test for structural change in the sensitivity of capital flows to interest rate differentials is reported.

The results show a significant increase in the sensitivity of cash capital flows to interest rate arbitrage following the September 1993 reform, indicating that this reform effectively liberalized the capital account

\footnotetext{
${ }^{37}$ Owing to the cointegrated nature of the series involved, the spurious regression risk is eliminated.
}

regime. The different specifications used illustrate the robustness of this conclusion. Indeed, the Chow test for structural change indicates that the null hypothesis of equal sensitivity of cash capital flows to interest rate differentials before and after the 1993 liberalization reforms are rejected under all specifications. Furthermore, the results show that, whereas capital flows were highly sensitive to interest rate differentials after September 1993, such an interest arbitrage effect is not statistically robust for the pre-liberalization period, as reflected in the implicit t-statistics of the estimated coefficients.

\section{Term structure of external debt}

The econometric results presented above show that capital controls had a significant impact on the volume of net capital inflows. An additional issue in evaluating their effectiveness is whether they have induced a more favourable term structure in Colombia's foreign debt. This is of particular interest because, as we have seen, the literature on financial crises has pointed out that excessive reliance on short-term debt increases a country's vulnerability and exposure to such crises. Based on annual data, panel A of figure 5 presents the term structure of private foreign debt. As shown, the share of short-term debt out of total private debt fell significantly in Colombia during the 1990s. Indeed, this share, which had represented over $60 \%$ of foreign private debt at the beginning of the 1990 s, had fallen to less than $20 \%$ by the end of the decade. This drastic reduction was achieved between 1994 and 1998, which coincides with the intensive use of price-based controls on capital flows. Moreover, the stability of the share of short-term debt after 1997 suggests that the May 1997 regulation, which introduced peso-denominated reserve requirements on foreign debt for all loan maturities, did not constitute a perfect substitute for the previous system of controls based on dollar-denominated reserve requirements on foreign loans under a minimum maturity. This finding is supported by the evidence presented below.

Figure 5, panel B presents additional evidence on how reserve requirements have affected the term structure of external debt, based on monthly averages of central bank registrations of foreign-currency loans extended by financial institutions. ${ }^{38}$ The figure shows

\footnotetext{
${ }^{38}$ It is important to take into account that 0 - to 18 -month loans are basically associated with import and export financing, which has been exempt from reserve requirements since March 1996.
} 


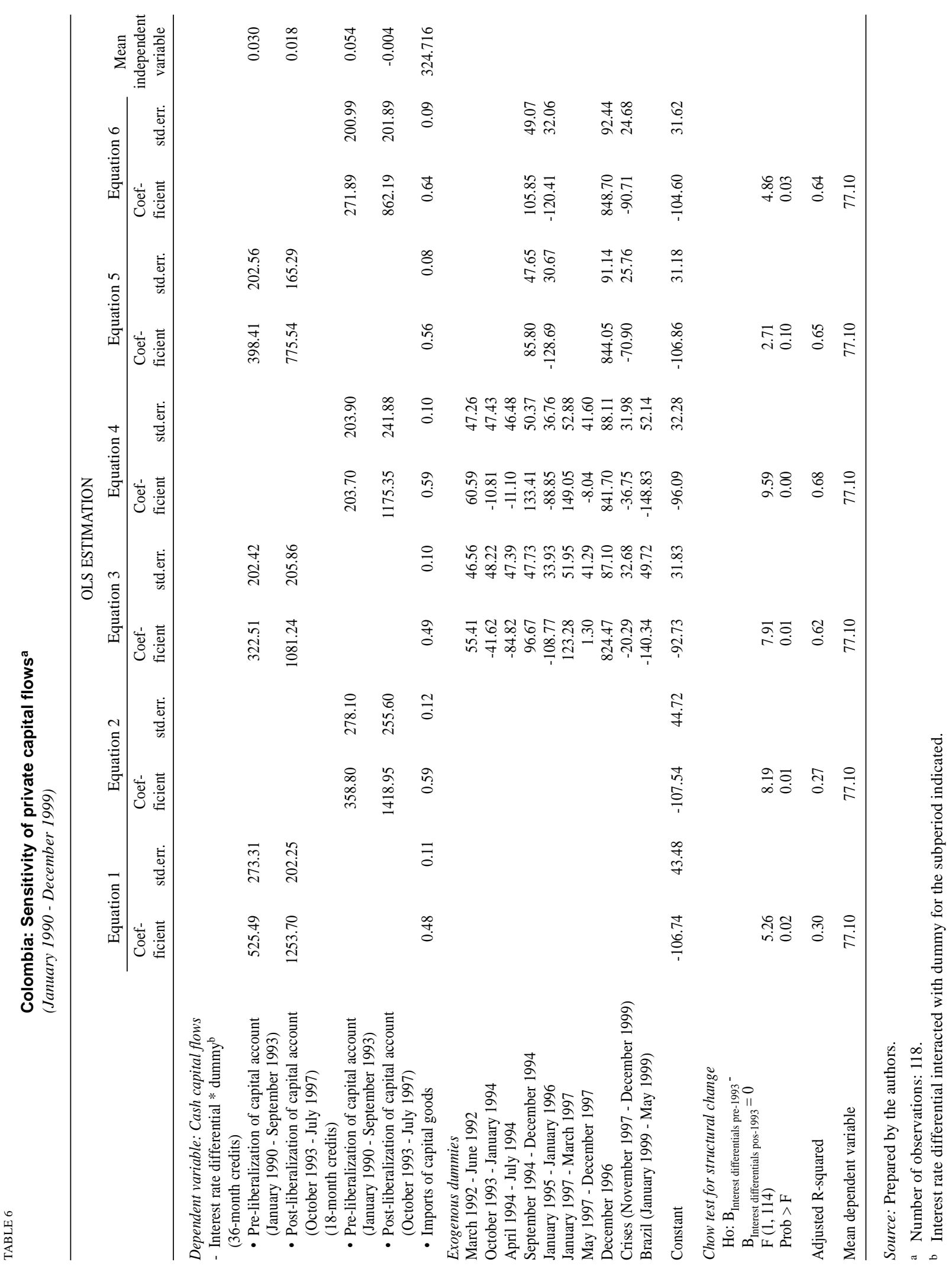


FIGURE 5

\section{Colombia: Term structure of external private debt}

A. External private debt balance

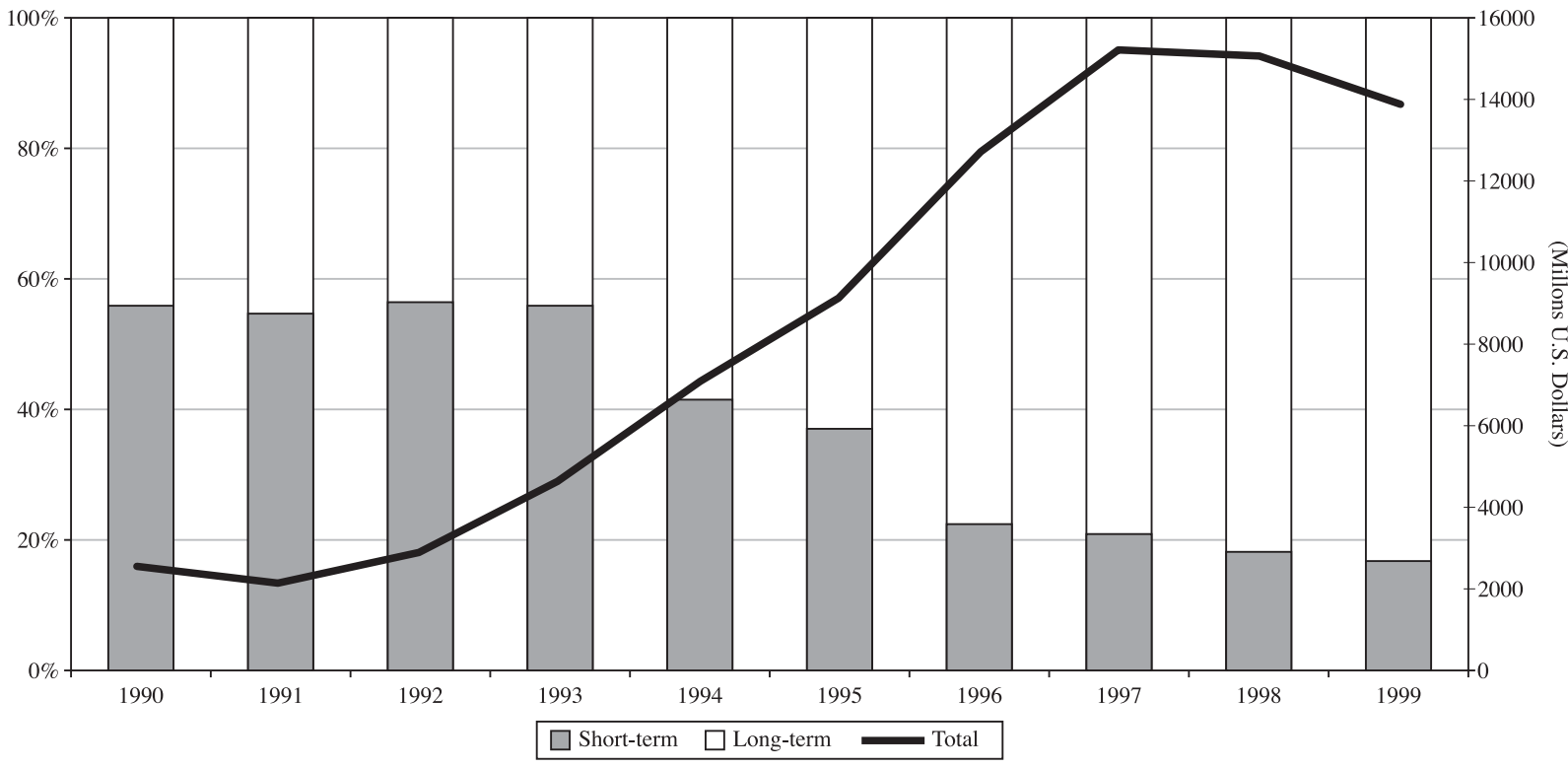

B. External debt registrations with foreign financial institutions according to loan maturities (\% share in total)

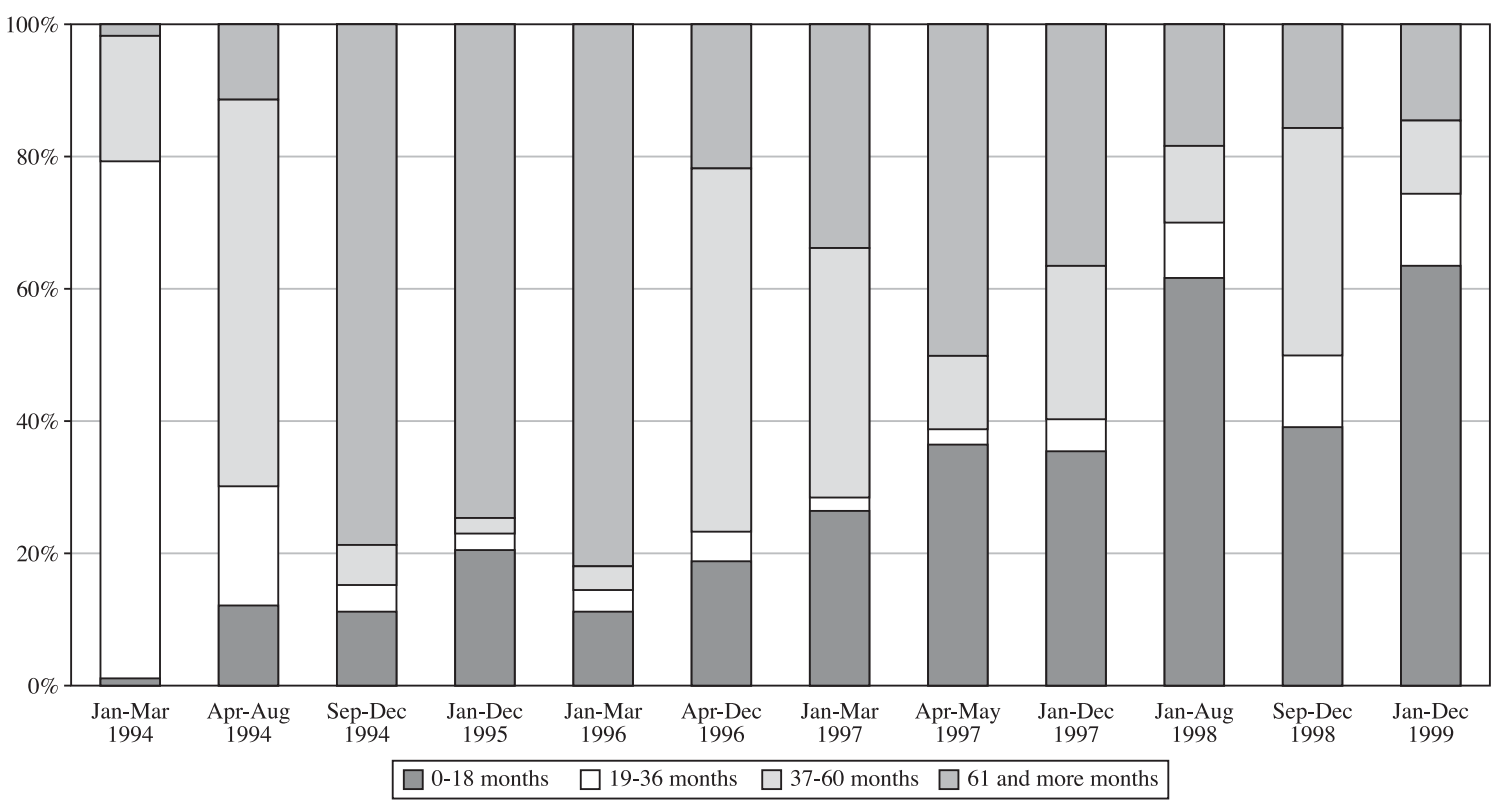

Source: Calculations based on data from the Central Bank of Colombia (Banco de la República). 
that the regulations implemented in March and August 1994 had a major impact on the term structure of foreign borrowing, as foreign debt registrations shifted towards a longer-term maturity structure. It is also evident that the liberalization policies of early

\section{V}

\section{Conclusions}

This paper has explored the effectiveness of price-based controls on capital inflows in Colombia in the 1990s. The effects of these controls are channeled through two different mechanisms. One is the interest rate differential, which reflects the higher cost of foreign borrowing. The other is associated with the discrete effects of changes in the regulatory system, which may be basically associated with the imperfect substitution between long-term and short-term borrowing. ${ }^{39}$

The econometric results support the conclusion that capital inflows are sensitive to interest rate differentials and, therefore, that price-based regulations on capital inflows effectively reduced the volume of capital inflows in Colombia. Also, the evidence presented indicates that these regulations improved the term structure of Colombia's external borrowing. The results also confirm that the September 1993 change in the capital account regime effectively liberalized the capital account by increasing the sensitivity of capital flows to interest arbitrage incentives.

The econometric evidence also indicates that reserve requirements did not have the same outcomes once the dollar-denominated requirements on loans under a certain minimum maturity were replaced, in May 1997, with a flat peso-denominated rate unrelated to the maturity of the loan. This suggests that the latter system was not a perfect substitute for previous regulations. In particular, the pre-May 1997 system had

\footnotetext{
${ }^{39}$ A number of studies on Chile and that of Cárdenas and Barrera (1997) on Colombia argue that controls on capital flows have been effective in altering the term structure of foreign debt but not the overall volume of capital inflows. This interpretation seems inconsistent, as it presupposes that long-term and short-term flows are perfect substitutes.
}

1996 shifted the term structure towards shorter maturities, while the tighter policies of January 1997 and March 1997 had the opposite effect. Lastly, the May 1997 regulations had an intermediate effect in this regard. stronger effects on the term structure of external borrowing. Also, the dollar-denominated system produced an interesting stabilizing effect on the cost of foreign borrowing in the face of nominal exchange rate fluctuations, whereas this effect was lost in the pesodenominated system.

Overall, the analysis suggests that price-based capital controls effectively play a dual policy role when a country experiences capital surges. On the one hand, they allow authorities to gain monetary and exchange rate control when under stronger pressure from capital inflows. This effect has also been confirmed in parallel research by Villar and Rincón (2003), using a different methodology. On the other hand, price-based regulations also constitute an effective "liability policy" that improves the term structure of external liabilities, thereby reducing liquidity risks.

This dual effect makes capital controls a desirable policy tool for reducing a country's vulnerability to sudden reversals of capital inflows. Their usefulness is enhanced by the fact that they are easily implemented, non-discretionary and preventive (prudential) in nature, since they penalize short-term foreign-currency liabilities more heavily. ${ }^{40}$

Lastly, it should be recalled that price-based capital controls, though effective in reducing capital inflows and improving the debt profile, are not a substitute for sound macroeconomic policies or for policies aimed at improving the prudential regulation and supervision of domestic financial systems.

\footnotetext{
40 Ocampo (2003a) compares these price-based controls to quantitative controls such as those employed in Malaysia during the Asian crisis.
} 
APPENDIX

Following Hansen and Juselius (1995), suppose the following p-dimensional vector autoregressive model of the type:

$$
z_{t}=A_{1} z_{t-1}+\ldots+A_{k} z_{t-\mathrm{k}}+\mu+\Psi D_{t}+\varepsilon_{t} \quad \mathrm{t}=1, \ldots, \mathrm{T} .
$$

where $z_{\mathrm{t}}$ is a px 1 vector of stochastic variables, $z_{t-\mathrm{k}+1}, \ldots, z_{0}$ are fixed, $\varepsilon_{1}, \ldots, \varepsilon_{\mathrm{t}}$ are niid $(0, \Sigma)$ and $D_{\mathrm{t}}$ is a vector of nonstochastic variables, such as intervention dummy variables.

This unrestricted vector autoregression model (VAR) involving k-lags of $z_{t}$ may be transformed into a vector error correction model (VECM):

$$
\text { [A.2] } \Delta z_{t}=\Gamma_{1} \Delta z_{t-1}+\ldots+\underset{\substack{k-1 \\ \varepsilon_{t} \sim \operatorname{niid}(O, \Sigma)}}{\Gamma_{t-\mathrm{k}+1}+\Pi z_{t-\mathrm{k}}+\mu+\Psi D_{t}+\varepsilon_{t}}
$$

The hypothesis of cointegration in equation A. 2 can be formulated as a reduced rank test of the П-matrix:

$$
H_{o}(r): \Pi=\alpha \beta \text {, }
$$

where $\alpha$ and $\beta$ are pxr matrices of full rank and $r$ indicates the number of cointegration vectors. Furthermore, the hypothesis $H_{o}(r)$ implies that the process $\Delta z_{\mathrm{t}}$ is stationary, $z_{\mathrm{t}}$ is nonstationary, but $\beta^{\prime} z_{\mathrm{t}}$ is stationary.

In our specific case, according to equation $8, z_{\mathrm{t}}$ is a $3 \mathrm{x} 1$ vector formed by the variables $K f, A$ and $g$, while $D_{\mathrm{t}}$ are intervention dummies $\delta_{i}$ and $\lambda_{i}$ that control for changes in the regulations on foreign borrowing and for supply shocks such as the tequila, Asian, Russian and Brazilian crises, respectively.

In order to understand the interpretation of the model, it is useful to expand some terms. Assuming, for simplicity's sake, that there are no deterministic components and that there is only one cointegration vector (i.e., $r=1$ ), we can write:

$$
\Pi z_{t-1}=\left[\begin{array}{c}
\alpha_{1} \\
\alpha_{2} \\
\alpha_{3}
\end{array}\right]\left[\beta_{1} \beta_{2} \beta_{3}\right]\left[\begin{array}{c}
K f \\
A \\
g
\end{array}\right]=\left[\begin{array}{c}
\alpha_{1} \\
\alpha_{2} \\
\alpha_{3}
\end{array}\right]\left[\beta_{1} K f+\beta_{2} A+\beta_{3} g\right]_{t-1}
$$

$$
\begin{gathered}
\Delta K f_{t}=\Gamma_{11} \Delta K f_{t-1}+\Gamma_{12} \Delta A_{t-1}+\Gamma_{13} \Delta g_{t-1} \\
+\tilde{\alpha}_{1}\left(K f_{t-1}+\left[\left(\begin{array}{c}
\beta_{2} \\
\beta_{1}
\end{array}\right) A_{t-1}+\left(\begin{array}{c}
\beta_{3} \\
\beta_{1}
\end{array}\right) \mathrm{g}_{t-1}\right]\right)+\varepsilon_{t}
\end{gathered}
$$

where $\tilde{\alpha}_{1} \alpha_{1} \beta_{1}$.

The cointegration relation A.4 (equation 9 in the text) is a stationary series, which is interpreted as a long-run equilibrium relation between the three variables $K f, A$ and $g$. If $\beta^{\prime} z_{t-1} \neq 0$, then it is interpreted as a long-run equilibrium error. On the other hand, $\tilde{\alpha}_{1}$, which is called the loading, measures the average speed of adjustment or convergence towards long-run equilibrium.

This analytical framework makes it possible to test whether a variable is weakly exogenous. For instance, the variable representing imports of capital goods, $g$, is said to be weakly exogenous for $\beta$ if $\alpha_{3}=0$ (see equation A.3), and therefore implies that the equation $\Delta g_{t}$ does not contain information about the long-run parameters $\beta$. In general, it is advantageous to condition the model on weakly exogenous variables as a means of improving the stochastic properties of the model. Furthermore, it is likely that the rest of the system will perform better statistically (see Hansen and Juselius, 1995; Enders, 1995; Harris, 1995).

\section{Tests used}

The test for the constancy of $\beta$ is a test of the hypothesis

$$
\mathrm{H} \beta_{\tau}: \tilde{\beta} \in \operatorname{sp}\left(\beta_{\tau}\right) \quad \tau=\mathrm{T}_{0}, \ldots, \mathrm{T} .
$$

where $\tilde{\beta}$ is a known matrix. In our case, $\tilde{\beta}$ is the cointegration vector estimated in equations 3 and 6 of table 4 .

The test statistic is given by:

$$
\begin{aligned}
-2 \ln \left(Q\left(\mathrm{H}_{\beta \tau} \mid \hat{\beta}(\tau)\right)\right) & =\tau \sum_{i=1}^{r}\left(\ln \left(1-\hat{\rho}_{i}(\tau)\right)-\ln \left(1-\hat{\lambda}_{i}(\tau)\right)\right. \\
\tau & =\mathrm{T}_{0}, \ldots, \mathrm{T}
\end{aligned}
$$

where $\hat{\rho}_{i}(\tau)$ are the solutions of:

$$
\text { [A.7] } \rho \tilde{\beta} S_{k k}(\tau) \tilde{\beta}-\tilde{\beta} S_{k 0}(\tau) S_{00}^{-1}(\tau) S_{0 k}(\tau) \tilde{\beta} \mid=0 \quad \tau=\mathrm{T}_{0}, \ldots, \mathrm{T} \text {. }
$$

and $\hat{\lambda}_{i}(\tau)$ are the $r$ largest eigenvalues in the unrestricted eigenvalue problem:

$$
\left|\lambda S_{k k}(\tau)-S_{k 0}(\tau) S_{00}^{-1}(\tau) S_{01}(\tau)\right|=0 \quad \tau=\mathrm{T}_{0}, \ldots, \mathrm{T} .
$$

The test statistic (A.6) is asymptotically distributed as $\chi^{2}$ with $\left(\mathrm{d}_{k}-r\right) r$ degrees of freedom (Hansen and Juselius, 1995). In our case, $d_{k}=5$ ( 3 variables, a constant and the row for the determinist variables) and $r=1$ (the number of cointegration vectors), hence the test is distributed $\chi^{2}(4)$. 


\section{References}

Agénor, Pierre-Richard and Peter Montiel (1999), Development Macroeconomics, second edition, Princeton, New Jersey, Princeton University Press.

Agosin, Manuel and Ricardo Ffrench-Davis (1999), "Capital flows in Chile: From the tequila to the Asian crises", in Journal of International Development, 11.

(1996), "Managing capital inflows in Latin America", in M. ul Haq, I. Kaul and I. Grunberg (eds.), The Tobin Tax Coping with Financial Volatility, New York, Oxford University Press.

Budnevich, Carlos and Le Fort, Guillermo (1997), "Capital account regulations and macroeconomic policy: two Latin American experiences", Documento de Trabajo 06, Santiago, Banco Central de Chile.

Calvo, Guillermo, Leonardo Leiderman and Carmen Reinhart (1996), "Inflows of capital to developing countries in the 1990s", Journal of Economic Perspectives, vol. 10, No. 2 (spring).

Cárdenas, Mauricio and Roberto Steiner (2000), "Private capital flows in Colombia", in F. Larraín (ed.), Capital Flows, Capital Controls and Currency Crises: Latin America in the 1990s, Michigan University Press, Ann Arbor.

Cárdenas, Mauricio. and Felipe Barrera (1997), "On the effectiveness of capital controls: The experience of Colombia during the 1990s", Journal of Development Economics, vol. 54.

De Gregorio, José, Sebastian Edwards and Rodrigo Valdés (2000), "Controls on capital inflows: do they work?", Journal of Development Economics, vol. 63, No. 1,October.

Edwards, Sebastian (1999), "How effective are capital controls?", Journal of Economic Perspectives, fall.

(1998), "Capital flows, real exchange rates and capital controls: some Latin American experiences", Working Paper 6800, Cambridge, National Bureau of Economic Research.

Eichengreen, Barry (1999), Toward a New International Financial Architecture: A Practical Post-Asian Agenda, Washington, D.C., Institute for International Economics (IIE).

Enders, Walter (1995), Applied Econometric Time Series, John Wiley and Sons.

Frankel, Jeffrey (1992), "Measuring international capital mobility: A review", The American Economic Review, vol. 82, issue 2. May.

Furman, Jason and Joseph Stiglitz (1998), "Economic Crises: Evidence and insights from East Asia", Brookings Papers on Economic Activity, 2.

Gourinchas, Pierre-Olivier, Rodrigo Valdés and Oscar Landerretche (2001), "Lending booms: Latin America and the World", NBER Working Paper, No. 8249. April.
Hansen, Henrik and Katerina Juselius (1995), Cats in Rats: Cointegration Analysis of Time Series, Estima.

Harris, Richard (1995), Using Cointegration Analysis in Econometric Modeling, Prentice Hall-Harvester-Wheatsheaf.

Montiel, Peter and Carmen Reinhart (1999), "Do capital controls and macroeconomic policies influence the volume and composition of capital flows? Evidence from the 1990s", Journal of International Money and Finance, No.18.

Ocampo, José Antonio (2003a), "Capital account and countercyclical prudential regulations in developing countries", in R. Ffrench-Davis and S. Griffith-Jones (eds.), From Capital Surges to Drought: Seeking Stability for Emerging Markets, Palgrave/Macmillan, London, forthcoming.

(2003b), "Developing countries' anti-cyclical policies in a globalized world", in Amitava Dutt and Jaime Ros (eds.), Development Economics and Structuralist Macroeconomics: Essays in Honour of Lance Taylor, Aldershot, United Kingdom, Edward Elgar.

Ocampo, José Antonio and Camilo Tovar (1997), "Capital flows, savings and investment performance in Colombia, 1990-1996", in R. Ffrench-Davis and H. Reisen (eds.), Capital Flows and Investment Performance: Lessons from Latin America, Paris, OECD-ECLAC.

Reinhart, Carmen and Steven Dunaway (1996), "Dealing with capital inflows: Are there any lessons?", Research for Action No.28, Helsinki, The United Nations University-WIDER.

Rincón, Hernán (1999), "Efectividad del control a los flujos de capital: un reexamen empírico de la experiencia reciente en Colombia”, Borradores Semanales de Economía, Bogotá, Banco de la República.

Rodrik, Dani and Andrés Velasco (2000), "Short-term capital flows", in Boris Pleskovic and Joseph E. Stiglitz (eds.), Annual World Bank Conference on Development Economics, 1999, Washington, D.C.

Schulze, Günther (2000), The political economy of capital controls, Cambridge, Cambridge University Press.

Valdés, Salvador and Marcelo Soto (1998), "The effectiveness of capital controls: theory and evidence from Chile", Empirica, No. 25, The Netherlands, Kluwer Academic Publishers.

Villar, Leonardo and Hernán Rincón (2003), "The Colombian economy in the nineties: capital flows and foreign exchange regimes", in Albert Berry (ed.), Critical Issues in Financial Reform: A View from the South, New Brunswick, New Jersey, Transaction Publishers, forthcoming.

Williamson, John and Molly Mahar (1998), "A survey of financial liberalization", Essays in International Finance, No. 211, Department of Economics, Princeton University, November. 